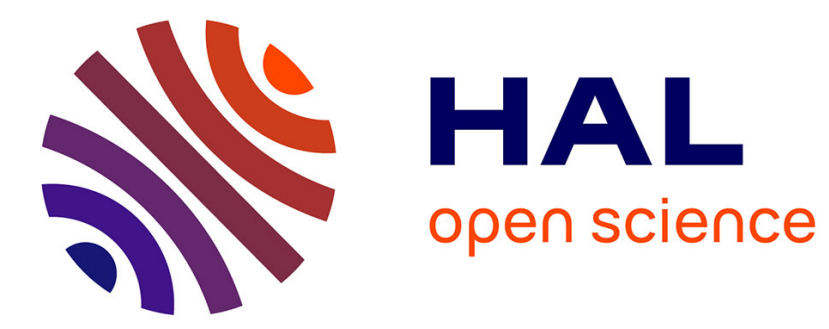

\title{
The Business Model of Social Banks
}

Simon Cornée, Panu Kalmi, Ariane Szafarz

\section{- To cite this version:}

Simon Cornée, Panu Kalmi, Ariane Szafarz. The Business Model of Social Banks. 2019. hal-02319133

\section{HAL Id: hal-02319133 \\ https://hal-univ-rennes1.archives-ouvertes.fr/hal-02319133}

Preprint submitted on 17 Oct 2019

HAL is a multi-disciplinary open access archive for the deposit and dissemination of scientific research documents, whether they are published or not. The documents may come from teaching and research institutions in France or abroad, or from public or private research centers.
L'archive ouverte pluridisciplinaire HAL, est destinée au dépôt et à la diffusion de documents scientifiques de niveau recherche, publiés ou non, émanant des établissements d'enseignement et de recherche français ou étrangers, des laboratoires publics ou privés. 


\title{
The Business Model of Social Banks*
}

\author{
Simon Cornée \\ Université de Rennes 1 / CREM UMR CNRS 6211 \\ Faculté des Sciences Economiques \\ 7, place Hoche CS 86514 \\ 35065 Rennes cedex \\ France \\ simon.cornee@univ-rennes1.fr \\ Panu Kalmi \\ University of Vaasa \\ Faculty of Business Studies \\ PO Box 700 \\ 65101 Vaasa \\ Finland \\ panu.kalmi@uwasa.fi \\ Ariane Szafarz** \\ Université Libre de Bruxelles (ULB), SBS-EM, CEB, and CERMi \\ 50, av. F.D. Roosevelt, CP114/03 \\ 1050 Brussels \\ Belgium \\ aszafarz@ulb.ac.be
}

\section{Forthcoming in Kyklos}

October 2019

JEL Classification: G20, L33, M14, L31, P13.

Keywords: Social banks; European banks; Business Model; Financial Intermediation; Social Enterprises.

* This study was supported by an 'Interuniversity Attraction Pole' on social enterprises funded by the Belgian
Science Policy Office, the Chair 'New Challenges in Banks: Social Responsibility, Efficiency, and Risks'
sponsored by the 'Fondation Rennes 1', the Academy of Finland (grant \#269130), and the OP Research
Foundation. The authors are grateful to the editor David Stadelmann and to two anonymous reviewers as well as
to Tony Bulger, Gaëtan Nicodème, François Rycx, and Véronique Thelen for their valuable comments, which
helped us improve this paper.

**Corresponding author 


\title{
The Business Model of Social Banks
}

\begin{abstract}
Based on an extensive literature review, this paper proposes to define social banks (SBs) as social enterprises that run banking activities with the social mission of supplying credit to other social enterprises, which are typically less profitable than for-profit businesses. This definition marks our starting point for developing a theoretical framework to explain how SBs survive without subsidies in the banking market. We build on a two-pillar business model of valuebased financial intermediation, which comprises an ownership structure that limits residual ownership claims and preferential credit conditions associated with financial sacrifices from motivated depositors. We also clarify the link between SBs and stakeholder banks and weigh up the importance of market interest rates for facilitating the business of SBs. An empirical analysis based on panel regressions on 5,400 European banks over the 1998-2013 period attests to the relevance of our theoretical framework. It also confirms that a low interest rate environment raises concerns about the sustainability of the SB business model.
\end{abstract}




\section{Introduction}

Social orientation makes a significant difference in banking (Barigozzi \& Tedeschi, 2015). Scholars nevertheless struggle to understand the business model of social banks (SBs). This paper attempts to fill this gap in the literature by proposing a definition of social banking. We suggest defining SBs as social enterprises (SEs) that finance other SEs. Accordingly, SBs lie at the intersection of banks and SEs. In line with this definition, our contribution is twofold. First, we suggest a two-pillar business model of value-based financial intermediation. The proposed model combines funders' financial sacrifices and favorable credit conditions for socially oriented borrowers. Second, we test our theoretical predictions on empirical data by exploiting a rich dataset on European banks.

Social banking has developed rapidly worldwide over the last two decades (GABV, 2012). Rough estimates indicate that, over the 1998-2013 period, the total assets of SBs grew twice as fast as those of other banks. Surprisingly then, there have been few studies carried out on SBs, and there is no universally accepted rigorous definition of social banking. Because Europe is the SB stronghold, research has focused mainly on social banking in the European context. Existing studies have uncovered some key features of SBs, which are often portrayed as double bottom line institutions, implying that profit-making is a way to achieve economic sustainability while adhering to social goals (Becchetti et al., 2011; Benedikter, 2011; San-Jose et al., 2011; Weber \& Remer, 2011). SBs support their communities and the common good through simple, transparent, and prudent intermediation principles. The financial transactions of SBs focus on funding the real economy rather than trading in speculative markets. Attention turned to SBs in the aftermath of the 2007-2008 financial turmoil. Many regular banks were found to have been insufficiently capitalized and had to be bailed out by taxpayers after taking excessive risks, prompting a search for alternative business models. Scholars have contributed to this quest by investigating the crisis performance of stakeholder banks (Ferri et al., 2015), 
Islamic banks (Beck et al., 2013a; Gheeraert \& Weill, 2015), community banks (Hudon \& Meyer, 2016), and other religiously oriented financial institutions (Mersland et al., 2013).

Our study extends the literature on alternative banking into the domain of social banking. The question underpinning this paper is: How can SBs survive without subsidies in the banking market? This question stems from the fact that SBs finance SEs, which are known to be less profitable than for-profit businesses. To resolve the apparent lack of understanding regarding SBs, this paper builds on a business model that comprises three groups of agents, namely owners, borrowers and depositors. The owner and depositor groups are the SB funders, motivated agents who are willing to accept a below-market return on their capital as long as the bank invests in social projects. The borrower group refers to the SEs that enjoy preferential credit conditions from the SBs (Borzaga \& Defourny, 2001). We test the relevance of this theoretical construct by using sample matching and panel regressions on 5,400 European banks over the 1998-2013 period. The results confirm that SBs benefit from a lower cost of funding, from both owners and deposit holders, and that they charge borrowers below-market interest rates. Our findings are consistent with the idea of investors and depositors passing on their earnings to social borrowers at sub-market rates. In addition, we reveal that while SBs are different from conventional banks (CBs), they nevertheless share characteristics with stakeholder banks. Finally, we show that SBs counteract rising interest rates in order to keep offering affordable rates to SE borrowers and that their business model suffers when market interest rates go down because it is difficult to grant loans with preferential rates when market rates are close to zero.

The paper is organized as follows. Section 2 introduces our proposed definition of a SB. Section 3 develops our theoretical predictions. Section 4 introduces the database and describes the empirical design. Section 5 discusses the regression results. Section 6 checks their robustness. Section 7 concludes. 


\section{What is a Social Bank?}

We define SBs as SEs that finance other SEs through banking activities. On the one hand, SBs are genuine banks, with the legal and practical implications this entails. From a legal perspective, this definitional feature excludes a number of social funding providers, including the many European microfinance institutions that are non-banking financial institutions (Cozarenco \& Szafarz, 2019). SBs are subject to the same fiscal and regulatory frameworks as their same-jurisdiction counterparts. As with regular banks, SBs develop a credit activity that is known to suffer from informational asymmetry. In line with the theory of financial intermediation (Diamond, 1984; Bhattacharya \& Thakor, 1993), SBs are required to overcome this information asymmetry in order to channel capital from (social) investors to (social) borrowers efficiently. Typical devices facilitating this include screening, selection, and monitoring mechanisms. In sum, SBs can be viewed as banks that have a specific pool of borrowers. On the other hand, SBs are SEs, and SEs are endeavors set up in pursuit of the common good (Peredo \& Chrisman, 2006). Profit maximization is not their primary objectivealthough generating profit is not ruled out (Besley \& Ghatak, 2017; Ghatak, 2019). They aim to internalize social costs and create positive externalities (Doherty et al., 2014). SEs can vary substantially in size, scale, and purpose due to the broad spectrum of products and services they supply (Borzaga \& Defourny, 2001). They typically promote the inclusion of disadvantaged people through work, ethical trade, organic food, renewable energies, recycling, community services provision (e.g. health and education services), subsidized housing, and so on (Dart, 2004; Di Domenico et al., 2010). 
The definition of a SE varies substantially from one side of the Atlantic to the other (Kerlin, 2006). ${ }^{1}$ In regard to the European context focused on in this study, the concept of SE first emerged in Italy with the introduction of social cooperatives in the 1990s. An authoritative and consensual formalization of the 'ideal-type' SE is provided by the EMES research network with its set of nine definitional characteristics, which are organized into two groups. The first group comprises four characteristics relating to the private-sector entrepreneurial nature of SEs: (i) continuous activity producing goods and/or services, (ii) large autonomy, (iii) significant risk level, (iv) minimum amount of paid work. The five characteristics in the second group encapsulate the social orientation of SEs: $(v)$ explicit social mission, $(v i)$ initiative from collective dynamics, (vii) democratic decision-making loosely related to ownership, (viii) stakeholder involvement, and (ix) limited profit distribution (Defourny \& Nyssens, 2008 \& 2010).

To justify defining SBs as SEs, we must explain how institutions that call themselves SBs meet these nine criteria. As banks, SBs possess the economic and entrepreneurial characteristics associated with SEs, that is they fulfill conditions $(i)$ to $(i v)$. SBs also fulfill criterion (v) because their explicit social mission is to fund other socially oriented organizations. This pivotal criterion marks the difference between cooperative/mutual organizations and social organizations. Finally, SBs fulfill criteria (vi) to (ix) because of their ownership and governance attributes. Profit is not their main objective but a means of achieving economic sustainability (Becchetti et al., 2011; Benedikter, 2011; Weber \& Remer, 2011; Mykhayliv \& Zauner, 2018). Many SBs operate with a stakeholder-ownership structure, either as a cooperative or as a savings bank. Shareholder-owned SBs use self-regulatory arrangements to constrain their

\footnotetext{
${ }^{1}$ American SEs are hybrid organizations (Austin et al., 2006) that tend to disconnect their business activity from their social goal. By contrast, SEs in continental Europe are more inclusive. Perhaps for this reason, social entrepreneurship still lacks an established epistemology (Nicholls, 2010), and its legitimation refers to actors, discourses, and narrative logics (Mair et al., 2012).
} 
owners' power. For example, the shareholders' voting rights are capped at Alternative Bank Schweiz (ABS, Switzerland) and Triodos Bank (Netherlands and Belgium). Alternative forms of stakeholder involvement are also promoted, such as the participation of non-shareholders in governing and executive bodies (San Jose et al., 2011). In short, SBs are enterprises because they are banks, and they are social enterprises because they have a social mission.

Defining SBs as SEs helps us to understand their raison d'être in the economy. By providing capital to SEs, SBs address a market gap because the regular credit market fails to meet SEs' demand for credit. Although SEs' activities cover a broad spectrum, their funding is plagued by two major issues. ${ }^{2}$ First, SEs cannot afford expensive credit. As double-or multiple - bottom line firms, SEs tend to create trade-offs between social mission and financial constraints (Wry \& York, 2017; Wry \& Zhao, 2018). Their businesses are typically less profitable than their for-profit counterparts (Defourny \& Nyssens, 2008 \& 2010). Second, in an asymmetric information context, the social orientation of SEs makes them even more opaque as borrowers than for-profit small and medium enterprises (SMEs), which are already known to be opaque (Berger \& Udell, 2002). The business activities of SEs, such as supplying welfarerelated and environmental services and hiring disadvantaged workers, are unfamiliar to standard bankers (Defourny \& Nyssens, 2008). Their financial sustainability depends on key features that are hard to quantify, such as relational capital, acquisition of non-market resources, and social value creation (Cornée, 2019). Regular banks are therefore ill-adapted to funding

\footnotetext{
${ }^{2}$ To cope with the pervasive lack of funds, SEs may undertake financial 'bricolage', a term referring to the improvisation and ingenuity used in circumventing financial obstacles (Di Domenico et al., 2010; Halme et al., 2012). SEs may also turn to crowdfunding opportunities and socially minded funders, such as impact investors (Lehner \& Nicholls, 2014; Kickul \& Lyons, 2015), who encourage social entrepreneurs to deliver observable social outcomes (Doherty et al., 2014). In addition, while the mutual funds driven by the principles of socially responsible investing claim to deliver both financial and social performances to investors (Barnett \& Salomon, 2012), a positive relationship between these performances raises doubts about the social accountability of the fund issuers (Laufer, 2003).
} 
SEs and unsurprisingly severely ration the funding they offer to this sector. This mismatch creates the opportunity that SBs seek to take advantage of.

To sum up, the nature of social banking is closely intertwined with that of SEs. Unlike regular banks, SBs do not aim to maximize profit but to target financial sustainability, and unlike conventional stakeholder banks, they purse an explicit social mission. The reason for their existence is the unmet demand for credit from non-banking SEs. However, our definition of SBs does not take into account the business model that allows these banks to be sustainable in the credit market. The next section addresses this issue by building a theoretical framework that rationalizes the existence of SBs in a capitalistic banking market.

\section{Hypothesis Development}

Defining SBs as banks with a social mission has certain implications. This section theorizes the implications, which are grouped into three categories, pertaining to both financial sustainability and banking activities. Section 3.1 hypothesizes a business model whereby SBs survive through the financial sacrifices of their motivated stakeholders. This core business model comprises two pillars: benevolent ownership and specific intermediation mechanisms. Hypothetically, these two pillars enable SBs to address market failure by supplying affordable credit to SEs. This SB business model thus consists in channeling the charitable contributions of socially minded agents to borrowing SEs. Sections 3.2 and 3.3 describe our theoretical framework further by clarifying the link between SBs and stakeholder-based ownership and by examining the impact of market interest rates on the SBs' intermediation scheme, respectively. The resulting set of hypotheses will be tested on the data in Section 5. 


\subsection{The Core Business Model of Social Banks: The Two Pillars}

The first pillar relates to ownership. Criteria (vi) to (ix) of EMES's definition of a SE state that ownership rights and profit distribution are limited, thereby implying that the owners of SEs are motivated by the social mission rather than by financial earnings. A direct implication for SBs is that their ownership is made up of motivated agents who consent to a financial outlay in order to serve the social mission of providing affordable credit to SEs. We therefore hypothesize that SBs collect capital at below-market conditions from motivated owners willing to support the development of SEs. Our first hypothesis states that the financial sacrifice of SB owners makes the return of SBs smaller than that of their CB counterparts.

Hypothesis H1: The returns delivered by SBs to their owners are smaller than those provided by $C B s$ :

$\Delta$ return $=\operatorname{return}(S B)-\operatorname{return}(C B)<0$

where return $(x)$ represents the return to owners of bank $x$, where $x \in\{S B, C B\}$.

The second pillar concerns the intermediation design. Like other banks, SBs carry out delegated monitoring on behalf of their investors (Diamond, 1984). We contend that their distinctive feature lies in the role of values in the intermediation process. Under H1, SB owners make financial sacrifices with respect to the market return available to them from other samerisk investment opportunities. However, benevolent or motivated ownership can be found in any industry, including banking. This next mechanism we propose relates specifically to the banking sector, and it revisits the intermediation model when exposed to social purpose, which is rather unusual. We consider the two sides of socially minded intermediation.

SBs explicitly claim to finance SEs by establishing strong lending relationships and charging below-market interest rates. To address the severe information asymmetry in SE 
financing, SBs draw on their experience in screening and monitoring social projects. Their hands-on experience stems from the social ties and human connections they have established with the social entrepreneurship milieu. This embeddedness is key to negotiating financial deals in informational environments where hard information ${ }^{3}$ is insufficient to assess credit risk confidently (Uzzi \& Lancaster, 2003; Duffner et al., 2009). In keeping with their mission and supported by micro evidence, SBs are able to offer more favorable credit conditions to their borrowers than CBs. In a lab setting, Cornée et al. (2012) show that social bankers charge a lower interest rate than commercial bankers. Using institution-specific data, Cornée and Szafarz (2014) find that the borrowers classed as 'social' by the SBs in question benefit from lower interest rates. Likewise, Becchetti et al. (2011) document that the SB in their study has an extremely high share of uncollateralized loans (around 42\%). Both these studies find that the borrowers receiving fair credit offers have a lower propensity to behave opportunistically. This is in line with the fact that reciprocity and social identification-either individually or in conjunction — are increasingly recognized as powerful mechanisms to combat moral hazard problems (Fehr et al., 1997; Akerlof \& Kranton, 2005; Chen \& Li, 2009). In sum, our hypothesis $\mathrm{H} 2$ theorizes that SBs master the lending technology that allows them to fulfill their mission.

Hypothesis H2. SBS support SEs by granting them loans at below-market interest rates:

$$
\Delta \text { intloan }=\text { intloan }(S B)-\operatorname{intloan}(C B)<0
$$

where intloan $(x)$ is the interest charged to borrowers of bank $x$, where $x \in\{S B, C B\}$.

Let us now turn to SB depositors. It is clear that SBs need to collect resources at belowmarket rates in order to be able to supply cheap credit to SEs. While some providers of social loans, such as microfinance institutions, receive subsidies and concessionary loans (Morduch,

\footnotetext{
${ }^{3}$ Hard information is defined by Berger et al. (2005) as quantitative facts derived from audited financial statements, personal data, and repayments history.
} 
1999; D’Espallier et al., 2013), this is not the case with SBs, which evolve in a competitive banking environment and rely on socially responsible investors accepting lower than normal financial returns (Riedl \& Smeets, 2017). In addition to motivated owners then, SBs need depositors who are willing to give up some remuneration of their capital to support the funding of social endeavors. However, the banking industry is plagued by asymmetric information, and SBs need credible commitments to convince depositors that low interest rates on deposits is not just another way for owners to make money. The main commitment devices mobilized by SBs relate to ownership structure and managerial design. Depositors are protected from owners' opportunism by statutory or self-designed provisions (San Jose et al., 2011) while managerial strategies include the social screening of borrowers, operational transparency, simple intermediation principles, and reasonable staff compensation (Cornée et al., 2016 \& 2018; Mykhayliv \& Zauner, 2018). ${ }^{4}$ This next hypothesis echoes recent evidence from Krause and Battenfeld (2019, p. 889) that the clients of German SBs have 'weaker preferences for financial, but stronger preferences for social return than conventional banking customers.'

Hypothesis H3. The remuneration of depositors by SBs is at below-market interest rates:

$\Delta \operatorname{intdep}=\operatorname{intdep}(S B)-\operatorname{intdep}(C B)<0$

where intdep $(x)$ represent the remuneration of deposits in bank, $x \in\{S B, C B\}$.

From an organizational standpoint, these three hypotheses emphasize the fact that SBs are hybrid entities (Billis, 2010) in the sense that they address social issues while also ensuring their own financial sustainability. We contend that this business model is specific to SBs. When

\footnotetext{
${ }^{4}$ Intuitively, using dual—social and financial—screening based on a relational approach should be more expensive than using a single, standard screening method (De Young et al., 2008). The issue of whether these additional costs are fully supported by the social investors is still a matter of debate. Cornée et al. (2018) find that SBs' costs are not significantly different from those of their mainstream counterparts. A plausible interpretation is that the extra screening time is compensated for by cheaper labor costs (because SB employees are motivated by the social mission and accept below-market wages).
} 
there is no social orientation, banks are unable to attract investors or depositors willing to make financial sacrifices.

\subsection{The Differential Effect of Ownership: Social Banks vs. Stakeholder banks}

Ownership is a broad concept that can cover different practices depending on the legal status of the company in question. Because we consider SBs to be SEs (with a limited profit distribution), we would expect SBs to adopt an ownership structure that restricts opportunities for profit distribution. SB owners can be either member-owners of stakeholder banks - a group that comprises savings banks and, predominantly, cooperative banks - or shareholders of a capitalistic bank. The literature shows that stakeholder banks are less profitable than shareholder banks and that they exhibit less-risky investment strategies (Iannotta et al., 2007; Périlleux et al., 2016), offering lower returns in absolute terms but higher risk-adjusted returns (Hesse \& Čihák, 2007). However, not all SBs are governed by a stakeholder ownership. In our sample, $39 \%$ of the SBs are governed by a shareholder status. As explained in Section 2, these SBs adopt self-regulatory arrangements aimed at limiting capital holders' residual claims in terms of remuneration and power and therefore at reassuring their various stakeholders, not least their depositors. In contrast, SBs with a stakeholder-based governance design have no specific ownership structure when compared to their same-governance conventional counterparts. Hence, as a complement to $\mathrm{H} 1$, we expect the lower profitability feature to be present predominantly, if not exclusively, within the group of shareholder banks. We therefore formulate the hypothesis that the profitability gap of SBs is similar to that of stakeholder banks.

Hypothesis H4: The returns delivered by stakeholder SBs (SBstake) to their owners are equal to those provided by stakeholder CBs (CBstake):

$\Delta \operatorname{return}(\operatorname{stake})=\operatorname{return}($ SBstake $)-\operatorname{return}($ CBstake $)=0$ 
where return $(x)$ represents the return to owners of bank $x$, where $x \in$ $\{$ SBstake, CBstake\}.

However, if $\mathrm{H} 4$ holds true, how are SBs different from other stakeholder banks? The answer to this question can be found in criterion $(v)$ of the definition of SEs: They pursue a stated social mission. While cooperative and mutual organizations are primarily oriented toward their members' interests, SBs serve a broad community and target the general interest (Gui, 1991; Kalmi, 2007). In the context of banking, cooperative banks carry out financial intermediation maximizing the interest of their membership by setting, for instance, borrowing rates that are favorable to their members (Angelini et al., 1998). SBs, on the other hand, finance projects of general interest and seek to offer attractive conditions to loans that promote the common good (Cornée \& Szafarz, 2014). ${ }^{5}$ In other words, we expect that the difference between conventional stakeholder banks and social stakeholder banks is to be found in their intermediation design, which in turn depends on their pool of borrowers.

The two next hypotheses are therefore similar to $\mathrm{H} 2$ and H3, but they apply exclusively to the restricted set of stakeholder banks.

Hypothesis H5. Stakeholder SBs support SEs by granting them loans at below-market interest rates:

$\operatorname{\Delta intloan}(\operatorname{stake})=\operatorname{intloan}($ SBstake $)-\operatorname{intloan}($ CBstake $)<0$

where intloan $(x)$ is the interest charged to borrowers of bank $x$, where $x \in$ $\{S$ coop, $C B$ coop $\}$.

\footnotetext{
${ }^{5} \mathrm{We}$ are not saying here that in pursuing the mutual interest, (conventional) stakeholder banks do not generate positive externalities, but these positive externalities are of a different nature (i.e. financial and economic), such as stabilizing the financial sector (Hesse \& Čihák, 2007) and mitigating any decrease in loan supply caused by monetary policy contractions (Ferri et al., 2014).
} 
Hypothesis H6. The remuneration of depositors by stakeholder SBs is at below-market interest rates:

$\Delta \operatorname{intdep}(\operatorname{stake})=\operatorname{intdep}($ SBstake $)-\operatorname{intdep}($ CBstake $)<0$

where $\operatorname{intdep}(x)$ represent the remuneration of deposits in bank $x$, where $x \in$ $\{$ SBstake, CBstake $\}$.

\subsection{The Impact of Market Interest Rates on the Intermediation Design of Social Banks}

Different types of institutions provide funding to SEs. According to the classification developed by Cornée et al. (2018), the continuum of social finance institutions includes foundations offering pure grants, ‘quasi-foundations' granting loans requiring only partial repayment, and SBs supplying soft loans. These institutions operate under a budget constraint that is dictated by their funders' generosity. SBs lie somewhere between charities that waive all or part of their capital reimbursement and standard commercial banks charging the market interest rate to their borrowers. Following this logic, the most social SBs charge near-zero interest rates while the least social SBs charge just-below-market rates. Consequently, the leeway of SBs may be represented by an interest rate segment that is circumscribed by a lower limit of zero and an upper limit of the market interest rate. Inevitably, this interval shrinks during periods of low interest rates. This variability allows us to extend our theory about the SB business model.

Let us consider the impact of the interest rates prevailing in the interbank market. These rates are the largest potential external factor impacting on the business model of banks. The banking literature reports on how bank characteristics, such as size, capitalization, and liquidity, influence the lending channel, i.e. how financial institutions adjust their credit supply and pricing following changes in monetary policy (Kashyap and Stein, 2000; Gambacorta, 2008). We complement this research by focussing on how a SB's social mission interferes with these 
adjustments and contend that SBs counteract rising market rates for two reasons. First, their main borrowers, SEs, cannot afford to pay high interest on their loans, so SBs tend to hold back the prices they charge. Second, as with stakeholder banks, using relational lending technology encourages SBs to smooth interest rate movements to help their clients manage transitions (Ferri et al., 2014).

H7. The market interest rate has a negative moderating effect on the lending rate of SBS:

$$
\frac{\text { dintloan }(S B)}{\text { dmarket rate }}<\frac{\text { dintloan }(C B)}{\text { dmarket rate }}
$$

Another manifestation of this strategy should be observable during periods where market interest rates experience an upward trend. Mirroring H7, which states that SBs tend to smooth their lending rates, we contend that SBs also smooth their deposit rates more than other banks in response to rising market rates.

H8. The market interest rate has a negative moderating effect on the deposit rate of SBS.

$$
\frac{\text { dintdep }(S B)}{\text { dmarket rate }}<\frac{\text { dintdep }(C B)}{\text { dmarket rate }}
$$

The unconventional monetary policy implemented by central banks in the aftermath of the 2007 Great Financial Crisis offers fertile ground for examining the effect of dramatically low interest rates on the intermediation features of SBs (Gerlach \& Lewis, 2014; Borio \& Gambacorta, 2017). ${ }^{6}$ Arguably, SBs are affected more than others when interest rates tend toward their zero bound because they can only keep the social spread on the loans they grant if they set negative rates on deposits, which is hardly feasible. Therefore, we predict that the

\footnotetext{
${ }^{6}$ Specifically, after the collapse of Lehman Brothers, central banks-including the European Central Bank-cut their interest rates aggressively (Gerlach \& Lewis, 2014). These interest rates were still low at the end of our sample period, i.e. December 2013 (Borio \& Gambacorta, 2017).
} 
second pillar of the SB business model is less efficient in a low interest rate environment than during normal periods. Our last two hypotheses formulate these predictions.

H9. A low-rate environment has a positive moderating effect on the lending rate of SBS. intloan $(S B$, normal $)-\operatorname{intloan}(S B$, low rate $)<\operatorname{intloan}(C B$, normal $)-\operatorname{intloan}(C B$, low rate $)$

H10. A low-rate environment has a positive moderating effect on the deposit rate of SBs.

$$
\operatorname{intdep}(S B, \text { normal })-\operatorname{intdep}(S B, \text { low rate })<\operatorname{intdep}(C B, \text { normal })-\operatorname{intdep}(C B \text {, low rate })
$$

Table 1 summarizes the set of hypotheses that will be investigated below.

\section{$* * *$ Insert Table 1 about here***}

\section{Data and Methods}

\subsection{Data}

Our data are retrieved from the Bankscope database provided by Bureau van Dijk. ${ }^{7}$ The period covered by the sample extends from 1998 to 2013. For sample homogeneity, we retain only those banks located in the group of 20 countries classified as 'Western Europe' (i.e. the fifteen pre-2004 European Union members plus Cyprus, Iceland, Malta, Norway, and Switzerland) and for which financial information is available. Eastern European countries are excluded from this study because their banking market differs considerably from that of Western Europe and because SBs seldom exist in Eastern Europe. From this sample of 6,524 pre-selected banks, we exclude real-estate banks, public banks, and the central institutions of cooperative groups. Realestate and public banks are dissimilar to commercial, cooperative, and savings banks (Hesse \& Čihák, 2007; Ferri et al., 2014 and 2015), and central cooperative institutions deal almost exclusively with intra-group transfers.

\footnotetext{
${ }^{7}$ Bankscope is a standard data source for banks' financial statements with a special focus on non-listed institutions (e.g. Gambacorta, 2005; Ashcraft, 2006; Iannotta et al., 2007; Ferri et al., 2014).
} 
Next, because SBs have no official status, we select the SBs in two steps. First, we assume that being a member of a SB organization guarantees the existence of a social mission. There are two such organizations: The European Federation of Ethical and Alternative Banks (FEBEA) and the Global Alliance for Banking on Values (GABV). FEBEA has 25 members. Twelve of these fulfill the necessary conditions for inclusion in our sample, that is they are located in Western Europe and they have the legal and fiscal status of a regular bank. Of the 55 worldwide members of GABV, we select the 15 banks operating in Western Europe. ${ }^{8}$ Because six of the banks belong to both FEBEA and GABV, our sample at the end of this first step comprises $21 \mathrm{SBs}$.

In the second step, we acknowledge that the literature (San Jose et al., 2011; Karl, 2015) also recognizes as social some institutions that are affiliated with neither FEBEA nor GABV. Applying geographic and statutory filters to these additional banks produces 25 potential SBs. However, because the literature is still vague on the definition of a $\mathrm{SB}$, we double-check these additional banks against our definition of a SB. To do this, we analyze the institution-specific information (webpage, annual reports, etc.) for each candidate to find out if their social mission is to serve SEs. Eight out of the 25 candidates are selected on this basis (see Table A1 in Appendix A). Most of the excluded banks are directly managing the money of religious institutions. Adding these eight SBs to the 21 previously selected members of FEBEA and/or GABV yields a final sample of 29 SBs.

We exclude the 9 countries (e.g. Ireland) in which no SBs are identified, but all the major European Union countries are nevertheless still represented in our final sample of 11 countries. Ultimately, our analysis starts with around 40,000 points-observations, approximately 300 of

\footnotetext{
${ }^{8}$ This group includes two banks (Ökobank $e G$ and IntegraBank eG München) that were taken over by GLS Gemeinschaftsbank $e G$ in 2003 and 2008, respectively.
} 
which relate to SBs (see Table 3). ${ }^{9}$ For all the banks, we use micro-level, unconsolidated, balance-sheet observations. There are two reasons for this. First, relying on unconsolidated data substantially increases the number of observations, especially for SBs with scant consolidated data. Dealing with unconsolidated data provides access to information from SBs that belong to conglomerates. For example, Crédit Coopératif is a subsidiary of France's BPCE, and Algemene Spaarbank voor Nederland (ASN) belongs to the Dutch bank SNS REAAL. Second, comparing SBs, which are generally assumed to be small in size, with the global players in the financial system could hamper our conclusions. Using unconsolidated data therefore automatically breaks down the networks and holding companies formed by large banking groups into smaller entities, making our comparison between SBs and CBs more germane. Admittedly, it is possible that size differences may still affect our analysis and so create a mismatch between the two groups in our study. The interest rates used as controls are retrieved from the Organisation for Economic Co-operation and Development (OECD) database that is available online (https://data.oecd.org/).

\subsection{Sample Matching}

Although the number of SB point-observations (300) is statistically sufficient for further analysis, they make up less than $1 \%$ of all the point-observations in the full sample. To address any potential biases stemming from both missing data and a sample imbalance between SBs and CBs (Rubin, 1973), we use sample matching. ${ }^{10}$ The idea is to match each SB with up to four of its nearest neighbors in the other group (Imbens \& Wooldridge, 2009).

To address the typical bias-variance trade-off in matching while also taking into account the lessons learned from the banking literature, we use a matching method based on the most

\footnotetext{
${ }^{9}$ To avoid outliers, we remove the observations corresponding to the first and last percentiles of all variables, except Loans to assets, Deposits to assets, Liquidity, and Log of assets (see Table 2).

${ }^{10} \mathrm{We}$ nevertheless run full-sample estimation as a robustness check.
} 
relevant characteristics (Pearl, 2000; King et al., 2011), hierarchized as country, ownership, and size. First, the dominance of a country relates to the key impact of jurisdiction on its banks' performance, market structure, and stability. As confirmed by Beck et al. (2013b), crosscountry heterogeneity stems from regulatory and institutional features. Second, ownership structure is a distinctive characteristic that determines a bank's legal social orientation, which in turn interplays with its value-based social orientation. This variable takes three forms, namely shareholder bank, cooperative bank, and savings bank (e.g. Ferri et al., 2014). ${ }^{11}$ Finally, bank size is instrumental in shaping features such as diversification (Demsetz \& Strahan, 1997), funding strategies (Demirgüc-Kunt \& Huizinga, 2010), interest-rate setting (Kishan \& Opiela, 2000), and profitability (Bourke, 1989). Matching is based on bank size as computed in 2005, the midpoint of our study time interval.

Our matching procedure consists of two steps. First, the banks are sorted by country, ownership, and size. Second, we match each SB with up to four same-country, same-ownershiptype CBs by using nearest-neighbor matching based on size (two above and two below). ${ }^{12}$ To rule out $\mathrm{CBs}$ with too few year-observations, there must be at least four occurrences in the dataset. Some SBs are matched with fewer than four CBs because above or below neighbors are missing in the same-country, same-ownership class. In sum, 24 SBs end up with four comparison banks, three with three, and the last two banks with only two.

\footnotetext{
${ }^{11}$ The only UK-based SB with the legal status of a building society was matched with non-social building societies. Common in the UK, building societies are financial cooperatives that originally only provided mortgage loans but which now supply a wide range of financial services. In this empirical analysis, we group together cooperative banks and savings banks into a category labelled 'stakeholder banks'.

${ }^{12}$ The only exception to the 'same-ownership-type' principle concerns the Dutch savings SB $A S N$, which is matched with Dutch shareholder banks of similar sizes. In fact, there is only one Dutch stakeholder bank in our sample, Rabobank, which is a cooperative bank. Its size is far too large to provide any relevant comparison.
} 


\subsection{Regression Model}

We use multiple balance-sheet proxies for the three theoretical variables in Equations (1) to (8). Table 2 lists the proxies as well as the control variables used in the regressions. Following the empirical design suggested by Beck et al. (2013a), we run the following regression for each independent variable, $Z$, shown in Table 2:

$Z_{i, j, t}=\alpha+\beta_{1} S B_{i, j}+\beta_{2} X_{i, j, t}+\beta_{3} M_{j, t}+C_{j}+T_{t}+\varepsilon_{i, t}$

where indices $i, j$, and $t$ stand for bank, country, and year, respectively, and where $S B$ is a dummy that takes value 1 if the bank is social, $X$ is a vector of characteristics that can vary according to the specification, $M$ is vector of macroeconomic conditions, and $C$ and $T$ are country and year fixed effects, respectively.

We use panel estimation because the banks in our sample are observed over several years. Hence, we run random-effect (RE) generalized-least-squares (GLS) models with standarderrors clustered at the bank level. Treating the residual bank effect as random (random bank effects) rather than fixed is appropriate because our SB dummy of interest is time invariant. While the RE estimator is the most efficient, its consistency requires the stringent assumption that the bank effects are uncorrelated with the $X$ vector. ${ }^{13}$ To gain consistency, we include country fixed effects.

\section{***Insert Table 2 about here***}

Our main goal is to test for differences between SBs and CBs. We have six proxy variables: two for Eq. (1), two for Eq. (2), and two for Eq. (3). The two proxies for owners' remuneration are: return on assets $(R O A)$ (net income over total assets) and risk-adjusted ROA

\footnotetext{
${ }^{13}$ The relevance of all the estimated RE-GLS models, as compared to OLS, is attested by the Lagrangian Multiplier (LM) test (Breusch and Pagan, 1980). The null hypothesis that the individual effect, $\mu_{i}$, equals zero is uniformly rejected at the $1 \%$ significance level.
} 
(RAROA). ROA is the standard profitability measure, so we use it in the main regressions. However, it fails to reflect the risk associated with the bank's business activity. As suggested by Mercieca et al. (2007), we therefore complement the analysis with risk-adjusted ROAs, which are sample means divided by the corresponding standard deviation as a robustness measure. Eq. (2) conjectures that SBs charge SEs below-market interest rates. The challenges in testing this hypothesis stem from the fact that we do not observe loan portfolios and that the interest that borrowers are charged depends on the riskiness of their projects. We use two proxies for the borrower interest rate: Interest rate on loans (interest income on loans over gross loans) and Interest rate on all earning assets (interest income over all earning assets). The first proxy is both accurate and unaffected by missing data. We use it in the baseline estimations. Finally, depositors' remuneration can be represented by two proxies: the interest expenses on all liabilities (Interest rate on liabilities) and the interest expenses on customer deposits (Interest rate on customer deposits). The second proxy is more accurate, but its use is compromised by missing data. For this reason, we prefer using the first proxy in the main regressions.

Vector X in Eq. (4) includes controls that could muddle the relationship between our dependent variables and Social bank. The list of controls, which comprises the abovementioned variables Log of assets and Stakeholder Ownership, is in keeping with the state of the art in the banking literature. Regarding Equity to assets, a positive link is often established between capitalization and ROA (e.g. Demirgüc-Kunt \& Huizinga, 2010). Bank efficiency, proxied by Overhead, contributes to profitability (Goddard et al., 2004), and low Overhead ratios should reduce the interest rate on loans and increase that of deposits (Gambacorta, 2008). Arguably, both bank owners and depositors may be inclined to ask for a premium on their remuneration as a function of the bank's liquidity (Diamond \& Dybvig, 1983), which also impacts lending strategies (Kashyap et al., 2002). 
A bank's asset and liability composition (Loans and Deposits) reflects its business orientation, which is key to its rate-setting policy and performance (Demirgüç-Kunt \& Huizinga, 1999). The impact of Credit risk — that is loan loss provisions over gross loans - on profitability is ambiguous (Iannotta et al., 2007). On the one hand, it might be positive to a certain extent because riskier loans lead to higher interest rates. On the other, high workout fees on defaulting loans harm profitability, and asset quality impairment raises the cost of funding (Mester, 1996). In line with the literature, we add the macroeconomic factors most likely to impact banking activities: Herfindahl-Hirschman market concentration index (Market concentration), overnight interbank rate (Interbank rate), inflation rate (Inflation), and GDP growth rate (GDP growth) (Bertay et al., 2013). Market concentration, Inflation, and GDP growth are computed at the country level, while Interbank rate is obtained at the monetaryzone level. ${ }^{14}$ Finally, the dummy variable Low Interest Rates captures the shift in monetary policy that followed the onset of the Great Financial Crisis, equaling zero until 2007 and one from 2008 onward (Borio \& Gambacorta, 2017).

\subsection{Descriptive Statistics}

Table 3 presents the means for both the SBs and the matched CBs and shows the t-test results for equal means. All the significant differences between the SB and CB dependent variable means have the signs predicted by our theoretical hypotheses. However, in respect of the profitability measures, the difference in means for $R A R O A$ is not statistically significant.

\section{$* * *$ Insert Table 3 about here***}

Table 3 provides insights into the variables that serve as controls in the next section. Because of the matching procedure, stakeholder banks are equally prevalent among CBs and

\footnotetext{
${ }^{14}$ Inflation rate and GPD growth rate are downloaded from the Bankscope database while the HerfindahlHirschman concentration index is computed from this database. Interbank rate is the yearly averaged overnight interbank rate (e.g. EONIA in the Eurozone) provided by the OECD.
} 
SBs. Matching narrows the gap in bank size between the two groups, in terms of both level (from $€ 3.3$ billion in the full sample to $-€ 1.2$ billion in the matched sample) and standard deviation (from $€ 52.59$ billion in the full sample to $€ 5.28$ billion in the matched sample). SBs have higher deposit-to-asset ratios and lower loan-to-asset ratios than CBs. Cornée et al. (2016) argue that this excess liquidity is indirect evidence that SBs adhere to their mission and select their borrowers rigorously. Nevertheless, high selectivity may be costly both financially and from a reputational point of view because it constrains the bank's ability to transform deposits from motivated savers into loans.

\section{Regression Analysis}

This section addresses the predictions about the SB business model, which are described in Subsections 3.1, 3.2, and 3.3, respectively.

\subsection{The Core Business Model}

The predictions formulated above about the core business model of SBs produced three hypotheses $(\mathrm{H} 1, \mathrm{H} 2, \mathrm{H} 3)$, which all relate to the sign and significance level of the SB dummy variable in different regressions.

Regarding the first pillar of the business model, we test whether SBs are less profitable than other banks (H1). This is a theoretical implication of the fact that socially minded investors are ready to accept a financial sacrifice to make the SB's mission possible. The regression results indicated in columns (1) and (2) of Table 4 support the idea of motivated ownership. SBs are associated with a decrease in $R O A$ of about 20 basis points, regardless of the inclusion of bank and macro control variables. H1 is empirically validated. 
Regarding the specific intermediation mechanism viewed as the second pillar of the SB core business model, we investigate whether, in terms of lending, SBs manage to offer more advantageous credit conditions than other banks. The intuition in $\mathrm{H} 2$ is that SB borrowers are SEs, and the banks' mission is to support these enterprises. The estimations reported in columns (3) and (4) of Table 4 focus on the loan interest rates. Both regressions confirm at the $1 \%$ level that SBs charge lower rates than their non-social counterparts. They suggest that SBs are passing their funders' financial sacrifice on to their borrowers, who benefit from an interest rate rebate of at least $140 \mathrm{bps}$ per annum. It could be argued that the interest rate differential between SBs and CBs is chiefly driven by differences in credit quality. To address this potential issue, we control for credit risk. Overall, $\mathrm{H} 2$ receives empirical confirmation.

In terms of the funding side of SBs, we check for the sacrifice made by SB depositors posited in H3. In columns (5) and (6) of Table 4, the dependent variable is a proxy of the interest rate on deposits, Interest rate on liabilities. Regarding sign and significance at the $1 \%$ level, both regressions deliver the same outcome, that is depositors' returns are significantly smaller in SBs than in their non-social counterparts. The point-estimates in columns (5) and (6) indicate a sacrifice of around 40 bps per annum, which is in line with H3. It could be argued that these results are driven by the fact that SB depositors choose distinctive, shorter-term savings products, making SB liabilities less remunerative when compared to those of their conventional counterparts. We cannot rule out this possibility, but it would contradict the evidence that socially responsible investors have a typically long-term focus (Cox et al., 2004). Taken together, the results support the hypotheses that both investors and depositors are willing to make financial sacrifices when putting money into SBs. 


\subsection{Social Banks and Stakeholder Banks}

Table 5 highlights the similarities between SBs and stakeholder banks. Despite the low levels of significance attributable to the matching procedure (see the full-sample regressions in Appendix B), the Stakeholder ownership dummy coefficients have the same signs as the SB coefficients. Hence, stakeholder banks have low profitability and use below-market lending interest rates. This can be attributed to their ability to address information asymmetries efficiently while refusing to use the resulting bargaining power to 'hold up' their borrowers (Angelini et al., 1998). Low rates on the liability side are, however, counterintuitive for cooperative banks, which constitute $71 \%$ of the stakeholder banks in our sample. Standard theory predicts that cooperative banks are expected to maximize the return on deposits (Smith

et al., 1981). In a historical perspective, both Banerjee et al. (1994) and Guinnane (1994) contend that high rates on deposits can help cooperative banks attract local savings and so prevent imbalances between net borrowers and net savers.

\section{$* * *$ Insert Table 5 about here $* * *$}

To disentangle the direct impacts both of SBs and of stakeholder status (applicable in $61 \%$ of cases), we rerun our baseline regressions in the sub-sample of stakeholder banks. In this sample, $\mathrm{H} 4$ predicts a zero impact on ROA, while $\mathrm{H} 5$ and $\mathrm{H} 6$ mimic the full-sample predictions about the loan and deposit rates. In column (1) of Table 5, we observe that the ROA delivered by SBs is not significantly different from that of other stakeholder banks, which validates $\mathrm{H} 4$. Columns (2) and (3) of Table 5 show that the levels of interest rates should be lower on both sides of the balance sheet given the explicit social orientation of SBs, thereby validating H5 and H6, respectively. 


\subsection{Social Banks and Market Interest Rates}

The monetary environment is key to financial intermediation. Our previous estimations acknowledge this evidence by controlling for the interbank interest rate, which conditions the interest rates set by banks on both sides of their balance sheets. We explore whether and, if so, how monetary environment affects the SB business model. In Table 6, we capture potential effects in two ways. First, we interact the Interbank rate with the Social Bank dummy (columns (1) and (3)). Second, we exploit the post-2007 low-interest period by interacting two dummies, Low interest rates and Social Bank (columns (2) and (4)). The empirical results support Hypotheses $\mathrm{H} 7$ to $\mathrm{H} 10$, however sometimes with only low significance. The overall message is twofold. First, when market interest rates move upward, SBs adopt smoothing strategies to offer affordable rates to SE borrowers and subsequently set lower deposits rates. Second, low interest rates can push the SB model toward its limits. Even socially oriented depositors would not accept capital meltdown because of negative interest rates. As a consequence, SBs cannot keep the social spread on lending rates.

\section{$* * *$ Insert Table 6 about here $* * *$}

\section{Robustness Checks}

\subsection{Alternative Samples}

The regression results from the matching procedure support our theoretical framework. However, the matching procedure drastically reduces the size of our dataset from 5,448 banks to 145 . In this section, we check whether the results from full-sample estimation are consistent with the matched-sample results. While full-sample estimation (in Tables B1 and B2) allows us to exploit the data from a large sample of banks, it exposes the results to sample imbalances linked to the small proportion-less than $1 \%$ - of SBs in the set. 
According to Table B1, our key findings on the impact of the Social bank dummy are also observable in the results obtained from both the full, all-bank sample (Panel A) and the sample made up of all stakeholder banks (Panel B). Table B2 reports the effects of market rates. These findings are aligned with the baseline results. In addition, the loading of the $S B *$ low interest rate interaction term gains statistical power.

Despite missing-data issues, the full-sample estimators have higher significance levels. The increase is particularly noticeable with some control variables, including the stakeholderbank dummy. The loadings of controls are in line with both the literature (see Section 4.3) and the results from our matching procedure (see Sections 5.1 to 5.3). Equity influences ROA positively. The cost variable Overhead pushes the loan interest rate upward and the interest rate on deposits downward. It is negatively related to profitability. Credit risk has a positive impact on both loan and deposit rates and a detrimental effect on profitability. Overall, meaningful control coefficients add consistency to our main results.

It could be argued that the second step in the SB selection process, described in Section 4.1, might be compromised by subjectivity. To address this concern, we carried out a robustness check by restricting the sample to just the 21 FEBEA and/or GABV members. The results shown in Table B3 are similar to those from the baseline regressions, albeit with a reduced statistical power, which is attributable to the smaller sample size.

\subsection{Alternative Variables}

Our hypotheses can be tested using alternative proxies for the dependent variables. In the baseline estimations, we use our preferred specifications for reasons pertaining to both accuracy and data availability. In Table B4, we present the results from the replicated analyses using alternative dependent variables but the same regressors. Specifically, we replace ROA, Interest rate on liabilities, and Interest rate on loans with RAROA, Interest rate on customer deposits, 
and Interest rate on all earning assets, respectively. Columns (1) and (4) explaining RAROA show that we use OLS estimation because RAROA is time invariant-it is the mean value of ROA divided by its standard deviation. For the sake of consistency, we also average the control variable over the sample period. The fixed country effects are still relevant.

Overall, the estimations displayed in Table B4 are consistent with our baseline results. However, it is worth mentioning that in the $R A R O A$ equation in Panel A, column (1), the loadings of the SB and stakeholder-bank dummies have opposite signs. Likewise, Panel B, which is restricted to stakeholder banks, shows that SBs are less profitable than stakeholder banks (at the 10\% level) when risk is accounted for in profitability. Our findings confirm those of Hesse and Čihák (2007), who find that conventional stakeholder banks have both low profitability and low return volatility. In addition, the SBs with stakeholder ownership have a higher return volatility than their conventional counterparts. This effect may stem from the inherent risks associated with funding ventures in the social sector. In Columns (9) and (10) of Panel C, the low significance levels of the interaction terms of interest are probably due to the limited sample size. Finally, a complementary regression analysis in which ROA is replaced either by the return on equity $(R O E)$ or by the risk-adjusted ROE (RAROE) delivers (unreported) estimations that are well aligned with the baseline results, both economically and statistically.

Table B5 presents the results from our analysis of the moderating effect of market concentration, which we conduct to assess the validity of our results when accounting for competition in the banking market (Fungácová et al., 2014). Banks that are active in a concentrated market tend to use their price-setting power in line with their bottom lines (Meyer, 2018). For profit-oriented banks, market power can typically translate into rising lending rates (D’Auria et al., 1999). By contrast, our results confirm the findings of previous studies (Cornée et al., 2012) that SBs do not take advantage of increased market power to raise the interest they 
charge. On the funding side, however, the negative and significant coefficient of the $S B^{*}$ market concentration interaction term is puzzling. It seems to indicate that SB depositors in concentrated markets are keener than others to accept smaller deposit remunerations. Hypothetically, in moderately concentrated markets, small-scale community or stakeholder banks compete with SBs to attract the money of socially minded depositors. An alternative rationale suggests there are behavioral factors at play, such as depositors' inattention, because SBs do not communicate on deposit remuneration. Overall, the estimated interaction effects add credibility to the theorized business model of social banking.

\subsection{Tests on Selection on Unobservables}

To address the issue of potential omitted variables, we run tests on selection on unobservables in line with the developments of Oster (2019), whose work extends that of Altonji et al. (2005). The Oster test exploits the information in R-squared changes when moving from uncontrolled to controlled regressions. We carry out the analysis from Eq. (11). Let $\hat{\beta}_{1}$ and $\breve{\beta}_{1}$ denote the estimated coefficients of Social bank with and without the observable controls, respectively, and $\hat{R}$ and $\breve{R}$ denote the corresponding $\mathrm{R}$-squared. To gauge the omitted variable bias of our estimates, we use the approximation of the bias-adjusted effect suggested by Oster (2019): ${ }^{15}$

$\beta_{1}^{*} \approx \tilde{\beta}_{1}^{*}=\hat{\beta}_{1}-\delta\left(\breve{\beta}_{1}-\hat{\beta}_{1}\right) \frac{R_{\max }-\hat{R}}{\widehat{R}-\breve{R}}$

where $R_{\max }$ is the R-squared of a hypothetical regression on the Social bank variable and both observed and unobserved controls. The test is as follows: If the interval delimited by $\hat{\beta}_{1}$ and $\tilde{\beta}_{1}^{*}$ excludes zero, then the value of $\hat{\beta}_{1}$ is not driven by omitted variables. As recommended by Oster (2019), we set $\delta$ to 1 , suggesting that the observables are at least as important as the

\footnotetext{
${ }^{15}$ The implementation of the Oster (2019) test is proposed as a Stata command ('psacalc'), developed by the author. Since this general procedure is still unavailable for our baseline RE-GLS model, we use the simple approximation formula obtained under the assumption that the unobservable and observables are equally related to the treatment (Oster, 2019).
} 
unobservables, and we use the values of 1 and 1.3 as $R_{\max }$ bounds. Based on the estimates from Table 4, Table B6 (in Appendix B) shows that none of the results from our baseline equations can be attributed to omitted variables.

\section{Conclusion}

While SBs have developed rapidly since the 2007 financial crisis and their asset growth has outpaced that of the conventional sector (Weber \& Remer, 2011), they are still a relatively small part of the banking sector. Nevertheless, their success justifies an increased scholarly interest in a business model that apparently manages to 'bank on' values. Positioned on the other side of the credit market, the future of the SE sector in Europe depends on the availability of funding. With mainstream banks often reluctant to lend to SEs, much of this sector has historically been reliant on public funding. SBs, which attract motivated fund providers willing to make financial sacrifices for social causes, represent an emerging alternative to public funding and mainstream banks for SEs.

To remain in business, however, SBs need to be financially sustainable. While the market gap they fill is delivering credit to SEs that are typically not profitable enough (or too risky) to obtain loans from $\mathrm{CBs}$, their business model, which takes advantage of social motivation, allows them to survive in a competitive credit market. This is a remarkable achievement, providing additional proof that the fruitful development of social economic initiatives in a market-oriented economy is possible without public subsidies. However, our results highlight the fragility of the original social banking business model when it faces a low interest rate environment. Low interest rates put SBs at risk because they compromise the sustainability of supplying below-market conditions to socially oriented borrowers.

The topic of social banking is a recent one in the academic literature, and both the boundaries of social banking and the differences between social and stakeholder (cooperative) 
banks are still unclear to many scholars. This paper contributes to clarifying these issues. It shows that, despite their essential differences, SBs and stakeholder banks share key characteristics. Our results suggest that both types of institutions serve the two sides of financial intermediation with interest rates that are lower than those prevailing in the banking marketalbeit the patterns exhibited by SBs are stronger. It is possible that these results stem from similarities in identity-based economic relationships. With both types of bank, non-financial considerations - shared social values for the SBs, and mutual interest and local embeddedness for the cooperatives - can motivate investors and depositors to make financial sacrifices. Financial support given for the common good or the community is channeled to borrowers by bankers who avoid diverting the deposited funds into speculative and premium-generating transactions. Our results also emphasize that limiting residual ownership rights is instrumental in the success of these alternative intermediation mechanisms.

Interestingly, our results offer promising avenues for future research on socially oriented financial institutions around the world. By providing a new, broader perspective on how SBs operate, the business model described in this paper proposes a framework for analyzing closely related organizations, such as microfinance institutions (some of which already belong to GABV). Like SBs, microfinance institutions often have access to cheaper resources on the liability side of their balance sheet, which enables them to target vulnerable borrowers and so increase their social performance. However, extending our framework to microfinance institutions means that two types of issues specific to the microfinance sector have to be addressed. First, the business models of most microfinance institutions still rely on subsidies to push forward their social agenda (D'Espallier et al., 2013; Cull et al., 2018). Second, formalizing a social mission is probably more complex for microfinance institutions than for SBs due to the prevalence of multiple heterogeneous objectives in the sector (Armendariz \& Szafarz, 2011; Mersland et al., 2019; Värendh Månsson et al., 2019). 
Our study cannot be accused of endogeneity because the social character of banks is chosen when they are founded. However, certain refinements of our conceptual approach could help elucidate both sides of the intermediation model presented in this paper. For example, on the funding side, a dynamic model could help scrutinize the development over time of features specific to SBs. In addition, monitoring the sacrifices that funders are willing to make could determine how long it takes to build a SB's reputation. A fruitful avenue for exploring the lending side further consists in gauging how SE heterogeneity impacts the SB business model. Moreover, the success of SBs and their propagation into mainstream banking groups raises new questions. For instance, what are the managerial implications of SBs joining CB groups? This issue and many others deserve further examination, for example through case studies.

Our results revive the debate about how social banking should be regulated. The current situation, that is the one-size-fits-all Basel framework, which is meant to level the playing field in international capital markets, is probably poorly adapted to the SB business model for several reasons (Ferri \& Neuberger, 2015). First, the Basel framework compels banks to rely exclusively on hard information to monitor credit risk and fulfill the regulatory capital requirements (Rajan et al., 2010). This view contradicts the fundaments of the relational approach needed to carefully serve SEs. Second, the Basel principles encourage banks to securitize their loan portfolios and use sophisticated financial products (Diamond \& Rajan, 2009), which is opposed to the transparency principles upheld by SBs. Finally, access to bank status is demanding in terms of compliance costs (Ferri \& Neuberger, 2015), which may explain why many socially oriented financial intermediaries in Europe opt for 'non-bank' status.

Adopting a holistic approach, this paper contributes to a better understanding of the SB business model. Given the recurrent issues faced by the mainstream financial system, much more can doubtless be learned from nascent efforts to explore alternative paths like social banking. 


\section{References}

Akerlof, G.A. and Kranton, R.E. (2005). Identity and the economics of organizations. Journal of Economic Perspectives, 19(1), 9-32.

Altonji, J.G., Elder, T.E., and Taber, C.R. (2005). Selection on observed and unobserved variables: Assessing the effectiveness of Catholic schools. Journal of Political Economy, 113(1), 151-184.

Angelini, P., Di Salvo, R., and Ferri, G. (1998). Availability and cost of credit for small businesses: Customer relationships and credit cooperatives. Journal of Banking \& Finance, 22(6-8), 925-954.

Armendariz, B. and Szafarz, A. (2011). On mission drift in microfinance institutions. In: B. Armendariz and M. Labie (Eds.), The Handbook of Microfinance, London-Singapore: World Scientific Publishing, 341-366.

Ashcraft, A.B. (2006). New evidence on the lending channel. Journal of Money, Credit \& Banking, 38(3), 751-776.

Austin, J., Stevenson, H., and Wei-Skillern, J. (2006). Social and commercial entrepreneurship: Same, different, or both? Entrepreneurship: Theory \& Practice, 30(1), 1-22.

Barigozzi, F. and Tedeschi, P. (2015). Credit markets with ethical banks and motivated borrowers. Review of Finance, 19(3), 1281-1313.

Banerjee, A.V., Besley, T. and Guinnane, T.W. (1994). Thy neighbor's keeper: The design of a credit cooperative with theory and a test. Quarterly Journal of Economics, 109(2), 491515.

Barnett, M. L. and Salomon, R.M. (2012). Does it pay to be really good? Addressing the shape of the relationship between social and financial performance. Strategic Management Journal, 33(11), 1304-1320. 
Becchetti, L., Garcia, M., and Trovato, G. (2011). Credit rationing and credit view: empirical evidence from loan data. Journal of Money, Credit \& Banking, 43(6), 1217-1245.

Beck, T., Demirgüç-Kunt, A., and Merrouche, O. (2013a). Islamic vs. conventional banking: Business model, efficiency and stability. Journal of Banking \& Finance, 37(2), 433-447.

Beck, T., De Jonghe, O., and Schepens, G. (2013b). Bank competition and stability: Crosscountry heterogeneity. Journal of Financial Intermediation, 22(2), 218-244.

Benedikter, R. (2011). Social Banking and Social Finance, New York: Springer.

Berger, A.N, Miller, N.H., Petersen, M.A., Rajan, R.G., and Stein, J.C. (2005). Does function allow organizational form? Evidence from the lending practices of large and small banks. Journal of Financial Economics, 76(2), 237-269.

Berger, A.N. and Udell, G.F. (2002). Small business credit availability and relationship lending: The importance of bank organizational structure. Economic Journal, 112(477), 34-53.

Bertay, A.C., Demirgüç-Kunt, A., and Huizinga, H. (2013). Do we need big banks? Evidence on performance, strategy and market discipline. Journal of Financial Intermediation, 22(4), 532-558.

Besley, T. and Ghatak, M. (2017). Profit with purpose? A theory of social enterprise. American Economic Journal: Economic Policy, 9(3), 19-58.

Bhattacharya, S. and Thakor, A. V. (1993). Contemporary banking theory. Journal of Financial Intermediation, 3(1), 2-50.

Billis, D. (Eds.), (2010). Hybrid organizations and the third sector: Challenges for practice, theory and policy. Basingstoke: Palgrave Macmillan.

Borio, C. and Gambacorta, L. (2017). Monetary policy and bank lending in a low interest rate environment: diminishing effectiveness? Journal of Macroeconomics, 54, 217-231.

Borzaga, C. and Defourny, J. (Eds.) (2001). The Emergence of Social Enterprise. London New York: Routledge. 
Bourke, P. (1989). Concentration and other determinants of bank profitability in Europe, North America and Australia. Journal of Banking \& Finance, 13(1), 65-79.

Breusch, T.S. and Pagan, A.R. (1980). The Lagrange multiplier test and its applications to model specification in econometrics. Review of Economic Studies, 47(1), 239-253.

Chen, Y. and Li, S. X. (2009). Group identity and social preferences. American Economic Review, 99(1), 431-57.

Cornée, S. (2019). The relevance of soft information for predicting small business credit default: Evidence from a social bank. Journal of Small Business Management, 57(3), pp. 699-719.

Cornée S., Jegers, M., and Szafarz, A. (2018). A theory of social finance. https://halshs.archives-ouvertes.fr/halshs-01717167.

Cornée, S., Kalmi, P., and Szafarz, A. (2016). Selectivity and transparency in social banking: Evidence from Europe. Journal of Economic Issues, 50(2), 494-502.

Cornée, S., Kalmi, P., and Szafarz, A. (2018). How costly is social screening? Evidence from the banking industry. Economics Bulletin, 38(1), 532-540.

Cornée, S., Masclet, D., and Thenet, G. (2012). Credit relationships: Evidence from experiments with real bankers. Journal of Money, Credit and Banking, 44(5), 957-980.

Cornée, S. and Szafarz, A. (2014). Vive la différence: Social banks and reciprocity in the credit market. Journal of Business Ethics, 125(3), 361-380.

Cox, P., Brammer, S., and Millington, A. (2004). An empirical examination of institutional investor preferences for corporate social performance. Journal of Business Ethics, 52(1), 27-43.

Cozarenco, A. and Szafarz, A. (2019). Microfinance in the North: Where do we stand? In: Hudon, M., Labie, M., and Szafarz, A. (Eds.) A Research Agenda for Financial Inclusion and Microfinance, Cheltenham (UK): Edward Elgar Publishing, 125-138. 
Cull, R., Demirgüç-Kunt, A., and Morduch, J. (2018). The microfinance business model: Enduring subsidy and modest profit. World Bank Economic Review, 32(2), 221-244.

Dart, R. (2004). The legitimacy of social enterprise. Nonprofit Management and Leadership, $14(4), 411-424$.

D’Auria, C., Foglia, A., and Reedtz, P.M. (1999). Bank interest rates and credit relationships in Italy. Journal of Banking \& Finance, 23(7), 1067-1093.

Defourny, J. and Nyssens, M. (2008). Social enterprise in Europe: Recent trends and developments. Social Enterprise Journal, 4(3), 202-228.

Defourny, J. and Nyssens, M. (2010). Conceptions of social enterprise and social entrepreneurship in Europe and United States: Convergences and divergences. Journal of Social Entrepreneurship, 1(1), 32-53.

Demsetz, R.S. and Strahan, P.E. (1997). Diversification, size, and risk at bank holding companies. Journal of Money, Credit \& Banking, 29(3), 300-313.

Demirgüç-Kunt, A. and Huizinga, H. (1999). Determinants of commercial bank interest margins and profitability: some international evidence. World Bank Economic Review, 13(2), 379-408.

Demirgüç-Kunt, A. and Huizinga, H. (2010). Bank activity and funding strategies: The impact on risk and returns. Journal of Financial Economics, 98(3), 626-650.

D’Espallier, B., Hudon, M., and Szafarz, A. (2013). Unsubsidized microfinance institutions. Economics Letters, 120(2), 174-176.

De Young, R., Glennon, D., and Nigro, P. (2008). Borrower-lender distance, credit scoring, and loan performance: Evidence from informational-opaque small business borrowers. Journal of Financial Intermediation, 17(1), 113-143.

Diamond, D.W. (1984). Financial intermediation and delegated monitoring. Review of Economic Studies, 51(3), 393-414. 
Diamond, D.W. and Dybvig, P.H. (1983). Bank runs, deposit insurance, and liquidity. Journal of Political Economy, 91(3), 401-419.

Diamond, D.W. and Rajan, R.G. (2009). The credit crisis: Conjectures about causes and remedies. American Economic Review, 99(2), 606-10.

Di Domenico, M., Haugh, H. and Tracey, P. (2010). Social bricolage: Theorizing social value creation in social enterprises. Entrepreneurship: Theory \& Practice, 34(4), 681-703.

Doherty, B., Haugh, H., and Lyon, F. (2014). Social enterprises as hybrid organizations: A review and research agenda. International Journal of Management Reviews, 16(4), 417436.

Duffner, S., Schmid, M.M., and Zimmermann, H. (2009). Trust and success in venture capital financing — an empirical analysis with German survey data. Kyklos, 62(1), 15-43.

Fehr, E., Gächter, S., and Kirchsteiger, G. (1997). Reciprocity as a contract enforcement device: Experimental evidence. Econometrica, 65(4), 833-860.

Ferri, G., Kalmi, P., and Kerola, E. (2014). Does bank ownership affect lending behavior? Evidence from the Euro area. Journal of Banking \& Finance, 48, 194-209.

Ferri, G., Kalmi, P., and Kerola, E. (2015). Organizational structure and performance in European banking: A Reassessment. Advances in the Economic Analysis of Participatory and Labor-Managed Firms, 16, 109-141.

Ferri, G. and Neuberger, D. (2015). The banking regulatory bubble and how to get out of it. In: Calciano, F., Fiordelisi, F., and Scarano, G. (Eds.). The Restructuring of Banks and Financial Systems in the Euro Area and the Financing of SMEs. London: Palgrave Macmillan, 31-61.

Fungácová, Z., Solanko L., and Weill, L. (2014). Does competition influence the bank lending channel in the euro area? Journal of Banking \& Finance, 49, 356-366.

GABV (2012), Global Alliance for Banking on Values. Annual Report. 
Gambacorta, L. (2005). Inside the bank lending channel. European Economic Review, 49(7), $1737-1759$.

Gambacorta, L. (2008). How do banks set interest rates? European Economic Review, 52(5), $792-819$.

Gerlach, S. and Lewis, J. (2014). Zero lower bound, ECB interest rate policy and the financial crisis. Empirical Economics, 46(3), 865-886.

Ghatak, M. (2019), 'Economic Theories of the Social Sector: From Nonprofits to Social Enterprise', in Powell, W.W. and P. Bromley (Eds.), The Nonprofit Sector: A Research Handbook, 3rd Edition, Palo Alto: Stanford University Press, Forthcoming.

Gheeraert, L. and Weill, L. (2015). Does Islamic banking development favor macroeconomic efficiency? Evidence on the Islamic finance-growth nexus. Economic Modelling, 47, 32 39.

Goddard, J., Molyneux, P., and Wilson, J. O. (2004). The profitability of European banks: a cross-sectional and dynamic panel analysis. The Manchester School, 72(3), 363-381.

Gui, B. (1991). The economic rationale for the 'Third Sector'. Annals of public and cooperative economics, 62(4), 551-572.

Guinnane, T.W. (1994). A failed institutional transplant: Raiffeisen's credit cooperatives in Ireland, 1894-1914. Explorations in Economic History, 31(1), 38-61.

Halme, M., Lindeman, S., and Linna, P. (2012). Innovation for inclusive business: Intrapreneurial bricolage in multinational corporations. Journal of Management Studies, 49(4), 743-784.

Hesse, H. and Čihák, M. (2007). Cooperative banks and financial stability. IMF Working Paper 07/02, Washington: International Monetary Fund. 
Hudon, M. and Meyer, C. (2016). A case study of microfinance and community development banks in Brazil: Private or common goods? Nonprofit and Voluntary Sector Quarterly, 45(4), 116S-133S.

Iannotta, G., Nocera, G., and Sironi, A. (2007). Ownership structure, risk and performance in the European banking industry. Journal of Banking \& Finance, 31(7), 2127-2149.

Imbens, G.W. and Wooldridge, J.M. (2009). Recent developments in the econometrics of program evaluation. Journal of Economic Literature, 47(1), 5-86.

Kalmi, P. (2007). The disappearance of cooperatives from economics textbooks. Cambridge Journal of Economics, 31(4), 625-647.

Karl, M.A. (2015). Are ethical and social banks less risky? Evidence from a new dataset. Working Paper 96, DIW Berlin and Institut für Wirtschaftsforschung Halle.

Kashyap, A.K., Rajan, R., and Stein, J.C. (2002). Banks as liquidity providers: An explanation for the coexistence of lending and deposit-taking. Journal of Finance, 57(1), 33-73.

Kashyap, A. K. and Stein, J. C. (2000). What do a million observations on banks say about the transmission of monetary policy?. American Economic Review, 90(3), 407-428.

Kerlin, J.A. (2006). Social enterprise in the United States and Europe: Understanding and learning from the differences. Voluntas, 17(3), 247-263.

Kickul, J. and Lyons, T.S. (2015). Financing social enterprises. Entrepreneurship Research Journal, 5(2), 83-85.

King, G., Nielsen, R. Coberley, C., Pope, J., and Wells, A. (2011). Comparative effectiveness of matching methods for causal inference. Working Paper, Harvard University.

Kishan, R.P. and Opiela, T.P. (2000). Bank size, bank capital, and the bank lending channel. Journal of Money, Credit \& Banking, 32(1), 121-141. 
Krause, K. and Battenfeld, D. (2019). Coming out of the niche? Social banking in Germany: An empirical analysis of consumer characteristics and market size. Journal of Business Ethics, 155(3), 889-911.

Laufer, W.S. (2003). Social accountability and corporate greenwashing. Journal of Business Ethics, 43(3), 253-261.

Lehner, O.M. and Nicholls, A. (2014). Social finance and crowdfunding for social enterprises: A public-private case study providing legitimacy and leverage. Venture Capital, 16(3), $271-286$.

Mair, J., Battilana, J., and Cardenas, J. (2012). Organizing for society: A typology of social entrepreneuring models. Journal of Business Ethics, 111(3), 353-373.

Mercieca, S., Schaeck, K., and Wolfe, S. (2007). Small European banks: Benefits from diversification? Journal of Banking \& Finance, 31(7), 1975-1998.

Mersland, R., D'Espallier, B., and Supphellen, M. (2013). The effects of religion on development efforts: Evidence from the microfinance industry and a research agenda. World Development, 41, 145-156.

Mersland, R., Nyarko, S.A., and Szafarz, A. (2019), Mission drift in social enterprises: Do microfinance organizations walk the talk? Journal of Business Venturing Insights, https://doi.org/10.1016/j.jbvi.2019.e00117

Mester, L.J. (1996). A study of bank efficiency taking into account risk-preferences. Journal of Banking \& Finance, 20(6), 1025-1045.

Meyer, E. (2018). The new economic scenario and its impact on the cooperative banking business model. In Migliorelli, M. (Ed.) New Cooperative Banking in Europe, Palgrave Macmillan, Cham (Switzerland), pp. 29-46.

Morduch, J. (1999). The role of subsidies in microfinance: evidence from the Grameen Bank. Journal of Development Economics, 60(1), 229-248. 
Mykhayliv, D. and Zauner, K. G. (2018). The financial and economic performance of social banks. Applied Economics, 50(34-35), 3833-3839.

Nicholls, A. (2010). The legitimacy of social entrepreneurship: Reflexive isomorphism in a preparadigmatic field. Entrepreneurship: Theory \& Practice, 34(4), 611-633.

Oster, E. (2019). Unobservable selection and coefficient stability: Theory and evidence. Journal of Business \& Economic Statistics, 37(2), 187-204.

Pearl, J. (2000). Causality: Models, reasoning, and inference. Cambridge: Cambridge University Press.

Peredo, A.M., and Chrisman, J.J. (2006). Toward a theory of community-based enterprise. Academy of Management Review, 31(2), 309-328.

Périlleux, A., Vanroose, A., and D'Espallier, B. (2016). Are financial cooperatives crowded out by commercial banks in the process of financial sector development? Kyklos, 69(1), 108134.

Rajan, U., Seru, A., and Vig, V. (2010). Statistical default models of incentives. American Economic Review, 100(2), 1-5.

Riedl, A. and Smeets, P. (2017). Why do investors hold socially responsible mutual funds? Journal of Finance, 72(6), 2505-2550.

Rubin D. B. (1973). Matching to remove bias in observational studies. Biometrics, 29(1), 159183.

San Jose, L., Retolaza, J.L., and Gutierrez, J. (2011). Are ethical banks different? A comparative analysis using the radical affinity index. Journal of Business Ethics, 100(1), 151-173.

Smith, D.J., Cargill, T.J., and Meyer, R.A. (1981). Credit unions: An economic theory of a credit union. Journal of Finance, 35(2), 319-328.

Uzzi, B. and Lancaster, R. (2003). Relational embeddedness and learning: The case of bank managers and their clients. Management Science, 49(4), 383-399. 
Värendh Månsson, C., Wry, T., and Szafarz, A. (2019). Anchors Aweigh? Then Time to go Upstream. Why we Need to Theorize 'Mission' before 'Drift'. Academy of Management Review, Dialogue, forthcoming.

Weber, O. and Remer, S. (2011). Social banks and the future of sustainable finance. LondonNew York: Routledge.

Wry, T. and York, J. (2017). An identity-based approach to social enterprise. Academy of Management Review, 42(3), 437-460.

Wry, T. and Zhao, E. (2018). Taking tradeoffs seriously: Examining the contextually contingent relationship between social outreach intensity and financial sustainability in global microfinance. Organization Science, 29(3), 507-528. 


\section{List of Tables}

Table 1. Business Model: Predicted Signs

\begin{tabular}{c|c|c|c}
\hline Outcome & $\begin{array}{c}\text { Return on assets } \\
\text { (ROA) }\end{array}$ & Rate charged to borrowers & Rate paid to depositors \\
\hline Treatment & H1: negative & H2: negative & H3: negative \\
\hline SB*stakeholder ownership & H4: null & H5: negative & H6: negative \\
\hline SB*market rate & & H7: negative & H8: negative \\
\hline SB*low interest rates & & H9: positive & H10: positive \\
\hline \hline
\end{tabular}

Table 2. Definition of Variables

\begin{tabular}{|c|c|}
\hline \multicolumn{2}{|l|}{ DEPENDENT VARIABLES } \\
\hline \multicolumn{2}{|l|}{ Owners' sacrifice } \\
\hline Return on assets (ROA, \%) & Net income / total assets \\
\hline Risk-adjusted ROA (RAROA, \%) & Mean ROA / standard deviation of ROA from 1998 to 2013 \\
\hline \multicolumn{2}{|l|}{ Lending rates } \\
\hline Interest rate on loans $(\%)$ & Interest income from loans / gross loans \\
\hline Interest rate on all earning assets $(\%)$ & All interest income / all earning assets \\
\hline \multicolumn{2}{|l|}{ Depositors' sacrifice } \\
\hline Interest rate on liabilities $(\%)$ & All interest expenses / all liabilities \\
\hline Interest rate on customer deposits $(\%)$ & Interest expenses from deposits / customer deposits \\
\hline \multicolumn{2}{|l|}{ INDEPENDENT VARIABLES } \\
\hline \multicolumn{2}{|l|}{ Bank-specific characteristics } \\
\hline Social bank & Dummy $=1$ if the bank is a social bank \\
\hline Stakeholder bank & Dummy $=1$ if the bank is a cooperative or savings bank \\
\hline Log of assets & $\log ($ total assets) \\
\hline Equity to assets $(\%)$ & Equity / total assets \\
\hline Overhead $(\%)$ & Operational costs / total assets \\
\hline Liquidity $(\%)$ & Loans / deposits \\
\hline Loans to assets $(\%)$ & Loans / total assets \\
\hline Deposits to assets $(\%)$ & Deposits / total assets \\
\hline Credit risk $(\%)$ & Loan loss provisions / gross loans \\
\hline \multicolumn{2}{|l|}{ Macroeconomic variables } \\
\hline Market concentration & Herfindahl-Hirschman market concentration index for assets \\
\hline Interbank rate $(\%)$ & Overnight interbank rate \\
\hline Inflation $(\%)$ & Inflation rate \\
\hline GDP growth (\%) & Growth rate of gross domestic product \\
\hline
\end{tabular}


Table 3. Summary Statistics: Social versus Conventional Banks

\begin{tabular}{|c|c|c|c|}
\hline Variables & $\begin{array}{l}\text { Social banks } \\
\text { (SBs) }\end{array}$ & Conventional banks (CBs) & $\begin{array}{l}\text { T-test for equal } \\
\text { means }\end{array}$ \\
\hline \multicolumn{4}{|l|}{ Dependent variables } \\
\hline Return on assets (ROA, \%) & $0.31(0.49),[\mathrm{N}=304]$ & $0.52(0.67),[\mathrm{N}=1,194]$ & $5.18 * * *$ \\
\hline Risk-adjusted ROA (RAROA, \%) & $1.37(1.18),[\mathrm{N}=26]$ & $2.11(2.29),[\mathrm{N}=104]$ & 1.58 \\
\hline Interest rate on loans $(\%)$ & $5.46(1.61),[\mathrm{N}=187]$ & $6.96(3.37),[\mathrm{N}=757]$ & $5.91 * * *$ \\
\hline Interest rate on all earning assets $(\%)$ & $4.42(1.28),[268]$ & $5.18(2.24),[\mathrm{N}=1,138]$ & $5.34 * * *$ \\
\hline Interest rate on liabilities $(\%)$ & $2.16(1.09),[\mathrm{N}=261]$ & $2.74(1.63),[\mathrm{N}=1,131]$ & $5.47 * * *$ \\
\hline Interest rate on customer deposits $(\%$ & $1.74(1.13),[\mathrm{N}=121]$ & $2.53(2.18),[\mathrm{N}=413]$ & $3.79 * * *$ \\
\hline \multicolumn{4}{|l|}{ Bank control variables } \\
\hline Stakeholder bank & $0.61(0.48),[\mathrm{N}=457]$ & $0.61(0.48),[\mathrm{N}=1,744]$ & -0.007 \\
\hline Log of assets & $6.15(1.93),[\mathrm{N}=307]$ & $5.92(1.77),[\mathrm{N}=1,268]$ & $-2.02 * *$ \\
\hline Equity to assets (\%) & $7.56(3.78),[\mathrm{N}=300]$ & $11.39(8.48),[\mathrm{N}=1,238]$ & $7.62 * * *$ \\
\hline Overhead $(\%)$ & $2.01(1.18)[\mathrm{N}=268]$ & $2.53(1.57)[\mathrm{N}=1,168]$ & $5.11 * * *$ \\
\hline Liquidity $(\%)$ & $85.03(38.60)[\mathrm{N}=286$ & $124.85(150.08)[\mathrm{N}=1,164$ & $4.45 * * *$ \\
\hline Loans to assets $(\%)$ & $54.48(21.40)[\mathrm{N}=296$ & $55.30(25.55)[\mathrm{N}=1,247]$ & 0.51 \\
\hline Deposits to assets $(\%)$ & $74.04(19.90)[\mathrm{N}=306$ & $61.08(26.73)[1,242]$ & $-7.95 * * *$ \\
\hline Credit risk $(\%)$ & $0.50(0.63)[\mathrm{N}=239]$ & $0.68(0.94)[\mathrm{N}=1,034]$ & $2.76 * * *$ \\
\hline \multicolumn{4}{|l|}{ Macro control variables } \\
\hline Market concentration & $0.17(0.13)[\mathrm{N}=457]$ & $0.17(0.13)[\mathrm{N}=1,712]$ & -0.56 \\
\hline Interbank rate $(\%)$ & $2.40(1.75)[\mathrm{N}=457]$ & $2.35(1.70)[\mathrm{N}=1,744]$ & -0.52 \\
\hline Inflation $(\%)$ & $1.89(0.92)[\mathrm{N}=457]$ & $1.86(0.93)[\mathrm{N}=1,744]$ & -0.57 \\
\hline GDP growth (\%) & $1.48(2.19)[\mathrm{N}=457]$ & $1.51(2.21)[\mathrm{N}=1,744]$ & 0.28 \\
\hline
\end{tabular}

Note: $* * *: \mathrm{p}<0.01, * *: \mathrm{p}<0.05, *: \mathrm{p}<0.1$. Standard errors are given in parentheses. The number $\mathrm{N}$ of pointobservations is given in brackets. 
Table 4. The Core Business Model of Social Banks

\begin{tabular}{|c|c|c|c|c|c|c|}
\hline \multirow[b]{2}{*}{ VARIABLES } & \multicolumn{2}{|c|}{ ROA } & \multicolumn{2}{|c|}{ Interest rate on loans } & \multicolumn{2}{|c|}{ Interest rate on liabilities } \\
\hline & $(1)$ & $(2)$ & (3) & (4) & (5) & $(6)$ \\
\hline Social bank & $\begin{array}{c}-0.29 * * * \\
(0.081)\end{array}$ & $\begin{array}{c}-0.24 * * * \\
(0.091)\end{array}$ & $\begin{array}{c}-1.44 * * * \\
(0.302)\end{array}$ & $\begin{array}{c}-1.61 * * * \\
(0.472)\end{array}$ & $\begin{array}{c}-0.47 * * * \\
(0.108)\end{array}$ & $\begin{array}{c}-0.44 * * * \\
(0.122)\end{array}$ \\
\hline Stakeholder ownership & & $\begin{array}{c}-0.004 \\
(0.139)\end{array}$ & & $\begin{array}{c}-1.83 * * \\
(0.786)\end{array}$ & & $\begin{array}{c}-0.06 \\
(0.175)\end{array}$ \\
\hline Log of assets & & $\begin{array}{l}0.08 * * \\
(0.032)\end{array}$ & & $\begin{array}{c}-0.31 \\
(0.230)\end{array}$ & & $\begin{array}{c}0.08 * \\
(0.045)\end{array}$ \\
\hline Equity to assets & & $\begin{array}{c}0.03 * * * \\
(0.009)\end{array}$ & & $\begin{array}{c}-0.08 * * \\
(0.037)\end{array}$ & & $\begin{array}{c}-0.02 * * \\
(0.010)\end{array}$ \\
\hline Overhead & & $\begin{array}{c}-0.07 \\
(0.049)\end{array}$ & & $\begin{array}{l}-0.20 * \\
(0.118)\end{array}$ & & $\begin{array}{l}-0.08 * * \\
(0.036)\end{array}$ \\
\hline Liquidity & & $\begin{array}{c}0.00 \\
(0.000)\end{array}$ & & & & $\begin{array}{l}-0.00 \\
(0.00)\end{array}$ \\
\hline Deposits to assets & & & & & & $\begin{array}{l}-0.01 * * \\
(0.005)\end{array}$ \\
\hline Loans to assets & & $\begin{array}{c}-0.000 \\
(0.002)\end{array}$ & & $\begin{array}{c}-0.05 * * * \\
(0.016)\end{array}$ & & \\
\hline Credit risk & & $\begin{array}{c}-0.23 * * * \\
(0.039)\end{array}$ & & $\begin{array}{c}0.18 \\
(0.124)\end{array}$ & & $\begin{array}{c}0.07 * * \\
(0.029)\end{array}$ \\
\hline Market concentration & & $\begin{array}{c}-0.35 \\
(0.332)\end{array}$ & & $\begin{array}{c}5.38 \\
(3.615)\end{array}$ & & $\begin{array}{c}1.19^{* *} \\
(0.553)\end{array}$ \\
\hline Interbank rate & & $\begin{array}{c}-0.10 * * \\
(0.046)\end{array}$ & & $\begin{array}{c}0.34 * * * \\
(0.083)\end{array}$ & & $\begin{array}{c}0.36 * * * \\
(0.032)\end{array}$ \\
\hline Inflation & & $\begin{array}{c}-0.01 \\
(0.029)\end{array}$ & & $\begin{array}{c}-0.16 \\
(0.099)\end{array}$ & & $\begin{array}{l}-0.07 * * \\
(0.032)\end{array}$ \\
\hline GDP growth & & $\begin{array}{c}0.03 * * \\
(0.014)\end{array}$ & & $\begin{array}{c}-0.05 \\
(0.050)\end{array}$ & & $\begin{array}{c}-0.07 * * * \\
(0.021)\end{array}$ \\
\hline Constant & $\begin{array}{c}0.54 * * * \\
(0.041)\end{array}$ & $\begin{array}{c}0.81 * * * \\
(0.285)\end{array}$ & $\begin{array}{c}6.78 * * * \\
(0.303)\end{array}$ & $\begin{array}{c}13.48 * * * \\
(2.241)\end{array}$ & $\begin{array}{c}2.59 * * * \\
(0.084)\end{array}$ & $\begin{array}{c}2.99 * * * \\
(0.664)\end{array}$ \\
\hline Country fixed effects & No & Yes & No & Yes & No & Yes \\
\hline Year fixed effects & No & Yes & No & Yes & No & Yes \\
\hline LM test & $480.66^{* * *}$ & $167.70 * * *$ & $1350.34 * * *$ & $518.19 * * *$ & $796.39 * * *$ & $1024.02 * * *$ \\
\hline \# Observations & 1,498 & 1,190 & 944 & 836 & 1,349 & 1,109 \\
\hline \# Banks & 135 & 124 & 115 & 111 & 132 & 124 \\
\hline $\mathrm{R} 2$ & 0.018 & 0.28 & 0.036 & 0.43 & 0.0246 & 0.71 \\
\hline
\end{tabular}

Note: $* * * \mathrm{p}<0.01, * * \mathrm{p}<0.05, * \mathrm{p}<0.1$. Random-effect GLS estimation with standard errors clustered at the bank level (in parentheses). LM = Lagrangian multiplier. 
Table 5. Social Banks and Stakeholder Ownership

\begin{tabular}{l|c|c|c}
\hline \hline & Stakeholder banks only & \multicolumn{2}{c}{$\begin{array}{c}\text { Interest rate on } \\
\text { liabilities }\end{array}$} \\
\hline VARIABLES & $(1)$ & Interest rate on loans & $(3)$ \\
\hline Social bank (SB) & & $(2)$ & $-0.37 * * *$ \\
& -0.05 & $-0.48^{* * *}$ & $(0.131)$ \\
Constant & $(0.070)$ & $(0.187)$ & $2.14^{* * *}$ \\
& $1.44^{* * *}$ & $8.41^{* * *}$ & $(0.529)$ \\
Bank \& Macro variables & $(0.339)$ & $(0.831)$ & Yes \\
Country fixed effects & Yes & Yes & Yes \\
Year fixed effects & Yes & Yes & Yes \\
\hline LM test & Yes & Yes & $743.70^{* * *}$ \\
\hline \# Observations & $102.64 * * *$ & $371.27 * * *$ & 785 \\
\# Banks & 841 & 577 & 83 \\
R2 & 83 & 76 & 0.75 \\
\hline \hline
\end{tabular}

Note: $* * * \mathrm{p}<0.01, * * \mathrm{p}<0.05, * \mathrm{p}<0.1$. Random-effect GLS estimation with standard errors clustered at the bank level (in parentheses). LM = Lagrangian multiplier.

Table 6. Social Banks and Market Interest Rates

\begin{tabular}{|c|c|c|c|c|}
\hline \multirow[b]{2}{*}{ VARIABLES } & \multicolumn{2}{|c|}{ Interest rate on loans } & \multicolumn{2}{|c|}{ Interest rate on liabilities } \\
\hline & $(1)$ & $(2)$ & (3) & $(4)$ \\
\hline Social bank (SB) & $\begin{array}{c}-1.20 * * * \\
(0.385)\end{array}$ & $\begin{array}{c}-1.77 * * * \\
(0.495)\end{array}$ & $\begin{array}{l}-0.30 * * \\
(0.122)\end{array}$ & $\begin{array}{c}-0.53 * * * \\
(0.135)\end{array}$ \\
\hline $\mathrm{SB} *$ interbank rate & $\begin{array}{l}-0.16^{*} \\
(0.085)\end{array}$ & & $\begin{array}{c}-0.07 \\
(0.043)\end{array}$ & \\
\hline $\mathrm{SB} *$ low interest rates & & $\begin{array}{c}0.49 * \\
(0.288)\end{array}$ & & $\begin{array}{l}0.18 * * \\
(0.090)\end{array}$ \\
\hline Interbank rate & $\begin{array}{c}0.36 * * * \\
(0.085)\end{array}$ & $\begin{array}{c}0.32 * * * \\
(0.082)\end{array}$ & $\begin{array}{c}0.37 * * * \\
(0.033)\end{array}$ & $\begin{array}{c}0.36 * * * \\
(0.033)\end{array}$ \\
\hline Low interest rates & & $\begin{array}{c}-3.40 * * * \\
(0.911)\end{array}$ & & $\begin{array}{c}-1.28 * * * \\
(0.169)\end{array}$ \\
\hline Constant & $\begin{array}{c}11.19 * * * \\
(1.854)\end{array}$ & $\begin{array}{c}11.27 * * * \\
(1.886)\end{array}$ & $\begin{array}{c}2.97 * * * \\
(0.650)\end{array}$ & $\begin{array}{c}3.02 * * * \\
(0.651)\end{array}$ \\
\hline All other control var. & Yes & Yes & Yes & Yes \\
\hline Country fixed effects & Yes & Yes & Yes & Yes \\
\hline Year fixed effects & Yes & Yes & Yes & Yes \\
\hline LM test & $523.67 * * *$ & $501.11 * * *$ & $1038.60 * * *$ & $892.63 * * *$ \\
\hline \# Observations & 836 & 836 & 1,109 & 1,109 \\
\hline \# Banks & 111 & 111 & 124 & 124 \\
\hline $\mathrm{R} 2$ & 0.43 & 0.44 & 0.71 & 0.70 \\
\hline
\end{tabular}

Note: ${ }^{* * *} \mathrm{p}<0.01,{ }^{*} \mathrm{p}<0.05, * \mathrm{p}<0.1$. Random-effect GLS estimation with standard errors clustered at the bank level (in parentheses). $\mathrm{LM}=$ Lagrangian multiplier. 


\section{The Business Model of Social Banks:}

\section{Supplementary Material}

\section{Appendix A: Selection of Social Banks}

Table A1. Sample of Social Banks

\begin{tabular}{|c|c|c|}
\hline Bank & Country & Legal status \\
\hline Andelskassen OIKOS & Denmark & Stakeholder (coop) bank \\
\hline Folkesparekassen* & Denmark & Stakeholder (savings) bank \\
\hline Merkur - Den Almennyttige Andelskasse* & Denmark & Stakeholder (coop) bank \\
\hline Crédit Coopératif* & France & Stakeholder (coop) bank \\
\hline La Nef* & France & Stakeholder (coop) bank \\
\hline Bank für Sozialwirtschaft Aktiengesellschaft* & Germany & Shareholder bank \\
\hline GLS Gemeinschaftsbank eG* & Germany & Stakeholder (coop) bank \\
\hline IntegraBank eG München* & Germany & Stakeholder (coop) bank \\
\hline Ökobank eG* & Germany & Stakeholder (coop) bank \\
\hline Steyler Bank GmbH & Germany & Shareholder bank \\
\hline UmweltBank AG* & Germany & Shareholder bank \\
\hline Banca Popolare Etica SPA* & Italy & Stakeholder (coop) bank \\
\hline Cassa Padana Banca di Credito* & Italy & Stakeholder (coop) bank \\
\hline Cassa Rurale di Bolzano Soc. Cooperativa* & Italy & Stakeholder (coop) bank \\
\hline Eticredito-Banca Etica Adriatica SpA & Italy & Shareholder bank \\
\hline APS Bank Limited* & Malta & Shareholder bank \\
\hline Algemene Spaarbank voor Nederland - ASN Bank NV & Netherlands & Stakeholder (savings) bank \\
\hline Triodos Bank NV* & Netherlands & Shareholder bank \\
\hline Cultura Sparebank* & Norway & Stakeholder (savings) bank \\
\hline Caja Laboral Popular Coop. de Credito & Spain & Stakeholder (coop) bank \\
\hline Colonya, Caixa d'Estalvis de Pollença* & Spain & Stakeholder (savings) bank \\
\hline Ekobanken medlemsbank* & Sweden & Stakeholder (coop) bank \\
\hline Alternative Bank Schweiz ABS* & Switzerland & Shareholder bank \\
\hline Freie Gemeinschaftsbank BCL* & Switzerland & Stakeholder (coop) bank \\
\hline CAF Bank Ltd & UK & Shareholder bank \\
\hline Charity Bank Limited (The)* & UK & Shareholder bank \\
\hline Co-operative Bank Plc (The) & UK & Shareholder bank \\
\hline Ecology Building Society (The)* & UK & Stakeholder (coop) bank \\
\hline Reliance Bank Limited & UK & Shareholder bank \\
\hline
\end{tabular}

Note: * member of GABV or FEBEA. 


\section{Appendix B: Robustness Checks}

Table B1. Alternative Sample: Full-Sample Regressions (1)

\begin{tabular}{|c|c|c|c|c|c|c|}
\hline \multirow[b]{2}{*}{ VARIABLES } & \multicolumn{3}{|c|}{ Panel A: Core business model } & \multicolumn{3}{|c|}{ Panel B: Stakeholder banks only } \\
\hline & $\begin{array}{l}\mathrm{ROA} \\
(1)\end{array}$ & $\begin{array}{l}\text { Int. rate on } \\
\text { loans } \\
\text { (2) }\end{array}$ & $\begin{array}{l}\text { Int. rate on } \\
\text { liabilities } \\
\text { (3) }\end{array}$ & $\begin{array}{l}\text { ROA } \\
\text { (4) }\end{array}$ & $\begin{array}{l}\text { Int. rate on } \\
\text { loans } \\
(5)\end{array}$ & $\begin{array}{c}\text { Int. rate on } \\
\text { liabilities } \\
\text { (6) }\end{array}$ \\
\hline Social bank (SB) & $\begin{array}{c}-0.23 * * \\
(0.103)\end{array}$ & $\begin{array}{c}-0.60 * * * \\
(0.221)\end{array}$ & $\begin{array}{c}-0.30 * * * \\
(0.098)\end{array}$ & $\begin{array}{c}-0.06 \\
(0.062)\end{array}$ & $\begin{array}{c}-0.37 * * \\
(0.163)\end{array}$ & $\begin{array}{c}-0.34 * * \\
(0.136)\end{array}$ \\
\hline Stakeholder ownership & $\begin{array}{c}-0.11 * * * \\
(0.027)\end{array}$ & $\begin{array}{c}-0.77 * * * \\
(0.124)\end{array}$ & $\begin{array}{l}-0.07 * * \\
(0.034)\end{array}$ & & & \\
\hline Log of assets & $\begin{array}{c}0.01 * * * \\
(0.005)\end{array}$ & $\begin{array}{c}-0.01 \\
(0.022)\end{array}$ & $\begin{array}{c}0.07 * * * \\
(0.007)\end{array}$ & $\begin{array}{c}-0.00 \\
(0.004)\end{array}$ & $\begin{array}{c}-0.01 \\
(0.016)\end{array}$ & $\begin{array}{c}0.05 * * * \\
(0.005)\end{array}$ \\
\hline Equity to assets & $\begin{array}{c}0.04 * * * \\
(0.003)\end{array}$ & $\begin{array}{c}0.00 \\
(0.009)\end{array}$ & $\begin{array}{c}-0.02 * * * \\
(0.003)\end{array}$ & $\begin{array}{c}0.06^{* * *} \\
(0.003)\end{array}$ & $\begin{array}{l}0.02 * * \\
(0.008)\end{array}$ & $\begin{array}{c}-0.02 * * * \\
(0.002)\end{array}$ \\
\hline Overhead & $\begin{array}{c}-0.06^{* * *} \\
(0.012)\end{array}$ & $\begin{array}{c}0.22 * * * \\
(0.038)\end{array}$ & $\begin{array}{c}-0.06 * * * \\
(0.011)\end{array}$ & $\begin{array}{c}-0.14 * * * \\
(0.011)\end{array}$ & $\begin{array}{c}0.35^{* * *} \\
(0.025)\end{array}$ & $\begin{array}{c}-0.08 * * * \\
(0.011)\end{array}$ \\
\hline Loans to assets & $\begin{array}{c}-0.00 \\
(0.000)\end{array}$ & $\begin{array}{c}-0.04 * * * \\
(0.002)\end{array}$ & & $\begin{array}{l}-0.00 * \\
(0.000)\end{array}$ & $\begin{array}{c}-0.04 * * * \\
(0.001)\end{array}$ & \\
\hline Liquidity & $\begin{array}{c}0.00 \\
(0.000)\end{array}$ & & $\begin{array}{c}0.00 * * * \\
(0.000)\end{array}$ & $\begin{array}{c}-0.00 * * * \\
(0.000)\end{array}$ & & $\begin{array}{l}0.00 * * \\
(0.000)\end{array}$ \\
\hline Deposits to assets & & & $\begin{array}{c}-0.01 * * * \\
(0.001)\end{array}$ & & & $\begin{array}{c}-0.01 * * * \\
(0.001)\end{array}$ \\
\hline Credit risk & $\begin{array}{c}-0.16^{* * *} \\
(0.006)\end{array}$ & $\begin{array}{c}0.04 * * * \\
(0.015)\end{array}$ & $\begin{array}{c}0.02 * * * \\
(0.004)\end{array}$ & $\begin{array}{c}-0.13 * * * \\
(0.006)\end{array}$ & $\begin{array}{c}0.05 * * * \\
(0.011)\end{array}$ & $\begin{array}{l}0.01 * * \\
(0.003)\end{array}$ \\
\hline Interbank rate & $\begin{array}{c}-0.05 * * * \\
(0.009)\end{array}$ & $\begin{array}{c}0.39 * * * \\
(0.030)\end{array}$ & $\begin{array}{c}0.38 * * * \\
(0.017)\end{array}$ & $\begin{array}{c}-0.06 * * * \\
(0.008)\end{array}$ & $\begin{array}{c}0.42 * * * \\
(0.020)\end{array}$ & $\begin{array}{c}0.44 * * * \\
(0.015)\end{array}$ \\
\hline Constant & $\begin{array}{l}1.02 * * * \\
(0.094)\end{array}$ & $\begin{array}{c}8.24 * * * \\
(0.408)\end{array}$ & $\begin{array}{c}2.61 * * * \\
(0.147)\end{array}$ & $\begin{array}{l}1.18 * * * \\
(0.078)\end{array}$ & $\begin{array}{c}7.07 * * * \\
(0.213)\end{array}$ & $\begin{array}{c}2.47 * * * \\
(0.136)\end{array}$ \\
\hline Other macro variables & Yes & Yes & Yes & Yes & Yes & Yes \\
\hline Country fixed effects & Yes & Yes & Yes & Yes & Yes & Yes \\
\hline Year fixed effects & Yes & Yes & Yes & Yes & Yes & Yes \\
\hline Observations (\#) & 42,666 & 35,289 & 39,974 & 36,700 & 30,872 & 34,472 \\
\hline Banks (\#) & 4,728 & 4,503 & 4,679 & 3,860 & 3,740 & 3,840 \\
\hline $\mathrm{R} 2$ & 0.30 & 0.55 & 0.73 & 0.40 & 0.74 & 0.83 \\
\hline
\end{tabular}

Note: $* * * \mathrm{p}<0.01, * * \mathrm{p}<0.05, * \mathrm{p}<0.1$. Random-effect GLS estimation with standard errors clustered at the bank level (in parentheses). 
Table B2. Alternative Sample: Full-Sample Regressions (2)

\begin{tabular}{|c|c|c|c|c|}
\hline \multirow{3}{*}{ Dependent variable } & \multicolumn{4}{|c|}{ Social banks and market interest rates } \\
\hline & \multicolumn{2}{|c|}{ Interest rate on loans } & \multicolumn{2}{|c|}{ Interest rate on liabilities } \\
\hline & (1) & (2) & (3) & (4) \\
\hline \multirow[t]{2}{*}{ Social bank (SB) } & $-0.46^{*}$ & $-0.77 * * *$ & $-0.23 * *$ & $-0.40 * * *$ \\
\hline & $(0.246)$ & $(0.224)$ & $(0.093)$ & $(0.117)$ \\
\hline \multirow[t]{2}{*}{$\mathrm{SB} *$ interbank rate } & $-0.08 *$ & & -0.04 & \\
\hline & $(0.046)$ & & $(0.036)$ & \\
\hline \multirow[t]{2}{*}{$\mathrm{SB} *$ low interest rates } & & $0.27 * *$ & & $0.17 * *$ \\
\hline & & $(0.116)$ & & $(0.069)$ \\
\hline \multirow[t]{2}{*}{ Stakeholder ownership } & $-0.77 * * *$ & $-0.77 * * *$ & $-0.07 * *$ & $-0.07 * *$ \\
\hline & $(0.124)$ & $(0.124)$ & $(0.034)$ & $(0.034)$ \\
\hline \multirow[t]{2}{*}{ Log of assets } & -0.02 & -0.02 & $0.07 * * *$ & $0.07 * * *$ \\
\hline & $(0.022)$ & $(0.022)$ & $(0.007)$ & $(0.007)$ \\
\hline \multirow[t]{2}{*}{ Equity to assets } & 0.00 & 0.00 & $-0.02 * * *$ & $-0.02 * * *$ \\
\hline & $(0.009)$ & $(0.009)$ & $(0.003)$ & $(0.003)$ \\
\hline \multirow[t]{2}{*}{ Overhead } & $0.22 * * *$ & $0.22 * * *$ & $-0.06 * * *$ & $-0.06 * * *$ \\
\hline & $(0.038)$ & $(0.038)$ & $(0.011)$ & $(0.011)$ \\
\hline \multirow[t]{2}{*}{ Loans to assets } & $-0.04 * * *$ & $-0.04 * * *$ & & \\
\hline & $(0.002)$ & $(0.002)$ & & \\
\hline \multirow[t]{2}{*}{ Liquidity } & & & $0.00 * * *$ & $0.00 * * *$ \\
\hline & & & $(0.000)$ & $(0.000)$ \\
\hline \multirow[t]{2}{*}{ Deposits to assets } & & & $-0.01 * * *$ & $-0.01 * * *$ \\
\hline & & & $(0.001)$ & $(0.001)$ \\
\hline \multirow[t]{2}{*}{ Credit risk } & $0.04 * * *$ & $0.04 * * *$ & $0.02 * * *$ & $0.02 * * *$ \\
\hline & $(0.015)$ & $(0.015)$ & $(0.004)$ & $(0.004)$ \\
\hline \multirow[t]{2}{*}{ Interbank rate } & $0.39 * * *$ & $0.39 * * *$ & $0.38 * * *$ & $0.38 * * *$ \\
\hline & $(0.030)$ & $(0.030)$ & $(0.017)$ & $(0.017)$ \\
\hline \multirow[t]{2}{*}{ Low interest rates } & & $-2.10 * * *$ & & $-1.34 * * *$ \\
\hline & & $(0.131)$ & & $(0.052)$ \\
\hline \multirow[t]{2}{*}{ Constant } & $8.24 * * *$ & $8.24 * * *$ & $2.61 * * *$ & $2.61 * * *$ \\
\hline & $(0.408)$ & $(0.408)$ & $(0.147)$ & $(0.147)$ \\
\hline Other macro variables & Yes & Yes & Yes & Yes \\
\hline Country fixed effects & Yes & Yes & Yes & Yes \\
\hline Year fixed effects & Yes & Yes & Yes & Yes \\
\hline Observations (\#) & 35,289 & 35,289 & 39,974 & 39,974 \\
\hline Banks (\#) & 4,503 & 4,503 & 4,679 & 4,679 \\
\hline $\mathrm{R} 2$ & 0.55 & 0.55 & 0.73 & 0.73 \\
\hline
\end{tabular}

Note: $* * * \mathrm{p}<0.01, * * \mathrm{p}<0.05, * \mathrm{p}<0.1$. Random-effect GLS estimation with standard errors clustered at the bank level (in parentheses). 
Table B3. Alternative Sample: Social Bank Members of FEBEA and/or GABV

\begin{tabular}{|c|c|c|c|c|c|c|c|c|c|c|}
\hline \multirow{3}{*}{ Dependent variable } & \multicolumn{3}{|c|}{ Panel A: Core business model } & \multicolumn{3}{|c|}{ Panel B: Stakeholder banks only } & \multicolumn{4}{|c|}{ Panel C: Social banks and market interest rates } \\
\hline & \multirow{2}{*}{$\frac{\mathrm{ROA}}{(1)}$} & \multirow{2}{*}{$\begin{array}{c}\begin{array}{c}\text { Int. rate on } \\
\text { loans }\end{array} \\
(2)\end{array}$} & \multirow{2}{*}{$\begin{array}{c}\begin{array}{c}\text { Int. rate on } \\
\text { liabilities }\end{array} \\
(3)\end{array}$} & \multirow{2}{*}{$\frac{\mathrm{ROA}}{(4)}$} & \multirow{2}{*}{$\begin{array}{c}\text { Int. rate on } \\
\text { loans } \\
(5)\end{array}$} & \multirow{2}{*}{$\begin{array}{c}\begin{array}{c}\text { Int. rate on } \\
\text { liabilities }\end{array} \\
(6)\end{array}$} & \multicolumn{2}{|c|}{ Int. rate on loans } & \multicolumn{2}{|c|}{ Int. rate on liabilities } \\
\hline & & & & & & & (7) & $(8)$ & (9) & $(10)$ \\
\hline Social bank & $\begin{array}{l}-0.16^{*} \\
(0.094)\end{array}$ & $\begin{array}{l}-0.77 * * \\
(0.313)\end{array}$ & $\begin{array}{c}-0.45 * * * \\
(0.155)\end{array}$ & $\begin{array}{c}-0.04 \\
(0.080)\end{array}$ & $\begin{array}{l}-0.49 * * \\
(0.205)\end{array}$ & $\begin{array}{l}-0.31 * \\
(0.162)\end{array}$ & $\begin{array}{c}-0.46 \\
(0.327)\end{array}$ & $\begin{array}{c}-1.15 * * * \\
(0.405)\end{array}$ & $\begin{array}{c}-0.41 * * * \\
(0.159)\end{array}$ & $\begin{array}{c}-0.52 * * * \\
(0.171)\end{array}$ \\
\hline SB*Interbank rate & & & & & & & $\begin{array}{l}-0.17^{*} \\
(0.097)\end{array}$ & & $\begin{array}{c}-0.02 \\
(0.042)\end{array}$ & \\
\hline SB*Low interest rates & & & & & & & & $\begin{array}{c}0.64 * \\
(0.334)\end{array}$ & & $\begin{array}{c}0.12 \\
(0.095)\end{array}$ \\
\hline Interbank rate & $-0.10^{*}$ & $0.43 * * *$ & $0.35 * * *$ & -0.07 & $0.32 * * *$ & $0.37 * * *$ & $0.49 * * *$ & $0.45 * * *$ & $0.36 * * *$ & $0.36 * * *$ \\
\hline Low interest rates & $(0.054)$ & $(0.125)$ & $(0.036)$ & $(0.047)$ & $(0.108)$ & $(0.038)$ & $(0.126)$ & $\begin{array}{c}(0.116) \\
-3.00 * * * \\
(0.825)\end{array}$ & $(0.038)$ & $\begin{array}{c}(0.038) \\
-1.05 * * * \\
(0.201)\end{array}$ \\
\hline Constant & $\begin{array}{l}1.01 * * \\
(0.484)\end{array}$ & $\begin{array}{c}9.14 * * * \\
(1.698)\end{array}$ & $\begin{array}{c}3.66^{* * *} \\
(0.758)\end{array}$ & $\begin{array}{l}1.54 * * * \\
(0.355)\end{array}$ & $\begin{array}{c}7.73 * * * \\
(0.899)\end{array}$ & $\begin{array}{c}2.63 * * * \\
(0.649)\end{array}$ & $\begin{array}{c}8.99 * * * \\
(1.677)\end{array}$ & $\begin{array}{c}9.23 * * * \\
(1.711)\end{array}$ & $\begin{array}{c}3.67 * * * \\
(0.763)\end{array}$ & $\begin{array}{c}3.72 * * * \\
(0.766)\end{array}$ \\
\hline Other bank \& macro var. & Yes & Yes & Yes & Yes & Yes & Yes & Yes & Yes & Yes & Yes \\
\hline Country fixed effects & Yes & Yes & Yes & Yes & Yes & Yes & Yes & Yes & Yes & Yes \\
\hline Year fixed effects & Yes & Yes & Yes & Yes & Yes & Yes & Yes & Yes & Yes & Yes \\
\hline Observations (\#) & 877 & 623 & 815 & 683 & 494 & 633 & 623 & 623 & 815 & 815 \\
\hline Banks (\#) & 92 & 81 & 92 & 68 & 63 & 68 & 81 & 81 & 92 & 92 \\
\hline $\mathrm{R} 2$ & 0.30 & 0.50 & 0.73 & 0.37 & 0.70 & 0.73 & 0.50 & 0.51 & 0.73 & 0.73 \\
\hline
\end{tabular}

Note: $* * * \mathrm{p}<0.01, * * \mathrm{p}<0.05, * \mathrm{p}<0.1$. Random-effect GLS estimation with standard errors clustered at the bank level (in parentheses). 
Table B4. Alternative Dependent Variables

\begin{tabular}{|c|c|c|c|c|c|c|c|c|c|c|}
\hline \multirow{3}{*}{ Dependent variable } & \multicolumn{3}{|c|}{ Panel A: Core business model } & \multicolumn{3}{|c|}{ Panel B: Stakeholder banks only } & \multicolumn{4}{|c|}{ Panel C: Social banks and market interest rates } \\
\hline & $\begin{array}{l}\text { RARO } \\
\text { A }\end{array}$ & $\begin{array}{l}\text { Int. rate on all } \\
\text { earning assets }\end{array}$ & $\begin{array}{l}\text { Int. rate on } \\
\text { customer } \\
\text { deposits }\end{array}$ & RAROA & $\begin{array}{l}\text { Int. rate on all } \\
\text { earning assets }\end{array}$ & $\begin{array}{l}\text { Int. rate on } \\
\text { customer } \\
\text { deposits }\end{array}$ & \multicolumn{2}{|c|}{$\begin{array}{l}\text { Int. rate on all earning } \\
\text { assets }\end{array}$} & \multicolumn{2}{|c|}{$\begin{array}{l}\text { Int. rate on customer } \\
\text { deposits }\end{array}$} \\
\hline & $(1)$ & $(2)$ & $(3)$ & $(4)$ & $(5)$ & $(6)$ & $(7)$ & $(8)$ & $(9)$ & $(10)$ \\
\hline Social bank & $\begin{array}{c}-1.01 * * \\
(0.420)\end{array}$ & $\begin{array}{c}-0.52 * * * \\
(0.183)\end{array}$ & $\begin{array}{c}-0.70^{* *} \\
(0.330)\end{array}$ & $\begin{array}{c}-1.03 * \\
(0.598)\end{array}$ & $\begin{array}{c}-0.39 * * \\
(0.162)\end{array}$ & $\begin{array}{c}-0.37 * * * \\
(0.131)\end{array}$ & $\begin{array}{l}-0.32 * \\
(0.193)\end{array}$ & $\begin{array}{c}-0.66^{* * *} \\
(0.205)\end{array}$ & $\begin{array}{l}-0.54^{*} \\
(0.304)\end{array}$ & $\begin{array}{l}-1.09 * * \\
(0.459)\end{array}$ \\
\hline SB*interbank rate & & & & & & & $\begin{array}{l}-0.11^{*} \\
(0.055)\end{array}$ & & $\begin{array}{c}-0.10 \\
(0.091)\end{array}$ & \\
\hline $\mathrm{SB}^{*}$ low interest rates & & & & & & & & $\begin{array}{c}0.24^{*} \\
(0.135)\end{array}$ & & $\begin{array}{c}0.54 \\
(0.338)\end{array}$ \\
\hline Interbank rate & $\begin{array}{c}-0.54 \\
(0.628)\end{array}$ & $\begin{array}{l}0.39 * * * \\
(0.104)\end{array}$ & $\begin{array}{c}0.56^{* * *} \\
(0.147)\end{array}$ & $\begin{array}{c}-0.32 \\
(0.675)\end{array}$ & $\begin{array}{l}0.28 * * * \\
(0.049)\end{array}$ & $\begin{array}{l}0.35 * * * \\
(0.034)\end{array}$ & $\begin{array}{l}0.41 * * * \\
(0.104)\end{array}$ & $\begin{array}{l}0.39^{* * *} \\
(0.103)\end{array}$ & $\begin{array}{l}0.58 * * * \\
(0.152)\end{array}$ & $\begin{array}{l}0.56 * * * \\
(0.149)\end{array}$ \\
\hline Low interest rates & & & & & & & & $\begin{array}{c}-1.90 * * * \\
(0.380)\end{array}$ & & $\begin{array}{c}0.90 \\
(0.951)\end{array}$ \\
\hline Constant & $\begin{array}{c}2.92 \\
(1.953)\end{array}$ & $\begin{array}{c}3.14 * * * \\
(0.726)\end{array}$ & $\begin{array}{c}1.02 \\
(1.656)\end{array}$ & $\begin{array}{c}6.59 \\
(4.264)\end{array}$ & $\begin{array}{c}3.53 * * * \\
(0.647)\end{array}$ & $\begin{array}{c}2.14 * * * \\
(0.530)\end{array}$ & $\begin{array}{l}3.11 * * * \\
(0.728)\end{array}$ & $\begin{array}{l}3.19^{* * *} \\
(0.725)\end{array}$ & $\begin{array}{c}0.93 \\
(1.627)\end{array}$ & $\begin{array}{c}1.06 \\
(1.597)\end{array}$ \\
\hline Other bank \& macro var. & Yes & Yes & Yes & Yes & Yes & Yes & Yes & Yes & Yes & Yes \\
\hline Country fixed effects & Yes & Yes & Yes & Yes & Yes & Yes & Yes & Yes & Yes & Yes \\
\hline Year fixed effects & No & Yes & Yes & No & Yes & Yes & Yes & Yes & Yes & Yes \\
\hline Observations (\#) & 118 & 1,168 & 459 & 78 & 787 & 785 & 1,168 & 1,168 & 459 & 459 \\
\hline Banks (\#) & 118 & 125 & 74 & 78 & 83 & 83 & 125 & 125 & 74 & 74 \\
\hline R2 & 0.32 & 0.51 & 0.55 & 0.38 & 0.79 & 0.76 & 0.51 & 0.51 & 0.56 & 0.56 \\
\hline
\end{tabular}


Table B5. Alternative Interaction: Market Concentration

\begin{tabular}{|c|c|c|c|c|}
\hline \multirow{2}{*}{ Dependent variable } & \multicolumn{2}{|c|}{ Interest rates on loans } & \multicolumn{2}{|c|}{ Interest rates on all deposits } \\
\hline & $(1)$ & $(2)$ & (3) & (4) \\
\hline Social bank (SB) & $\begin{array}{c}-1.34 * * * \\
(0.455)\end{array}$ & $\begin{array}{l}-1.16^{*} \\
(0.649)\end{array}$ & $\begin{array}{l}-0.31 * * \\
(0.127)\end{array}$ & $\begin{array}{c}-0.15 \\
(0.141)\end{array}$ \\
\hline SB*market concentration & & $\begin{array}{c}-3.11 \\
(2.728)\end{array}$ & & $\begin{array}{c}-1.75^{* * *} \\
(0.632)\end{array}$ \\
\hline Market concentration & $\begin{array}{c}5.47 \\
(3.615)\end{array}$ & $\begin{array}{c}5.95 \\
(3.936)\end{array}$ & $\begin{array}{l}1.17 * * \\
(0.549)\end{array}$ & $\begin{array}{l}1.44 * * \\
(0.581)\end{array}$ \\
\hline Constant & $\begin{array}{c}13.41 * * * \\
(2.221)\end{array}$ & $\begin{array}{c}13.30 * * * \\
(2.278)\end{array}$ & $\begin{array}{c}3.02 * * * \\
(0.660)\end{array}$ & $\begin{array}{c}2.91 * * * \\
(0.662)\end{array}$ \\
\hline All other control var. & Yes & Yes & Yes & Yes \\
\hline Country fixed effects & Yes & Yes & Yes & Yes \\
\hline Year fixed effects & Yes & Yes & Yes & Yes \\
\hline Observations (\#) & 836 & 836 & 1,109 & 1,109 \\
\hline Banks (\#) & 111 & 111 & 124 & 124 \\
\hline $\mathrm{R} 2$ & 0.43 & 0.42 & 0.71 & 0.72 \\
\hline
\end{tabular}

Note: ${ }^{* * *} \mathrm{p}<0.01,{ }^{*} \mathrm{p}<0.05, * \mathrm{p}<0.1$. Random-effect GLS estimation with standard errors clustered at the bank level (in parentheses).

Table B6: Selection on Unobservable Variables

\begin{tabular}{|c|c|c|c|c|c|c|}
\hline \multirow{2}{*}{ Dependent variable } & \multicolumn{2}{|c|}{ ROA } & \multicolumn{2}{|c|}{ Interest rate on loans } & \multicolumn{2}{|c|}{ Interest rate on liabilities } \\
\hline & $\begin{array}{c}\text { Uncontrolled } \\
\text { (1) } \\
\end{array}$ & $\begin{array}{c}\text { Controlled } \\
(2) \\
\end{array}$ & $\begin{array}{c}\text { Uncontrolled } \\
(3)\end{array}$ & $\begin{array}{c}\text { Controlled } \\
(4) \\
\end{array}$ & $\begin{array}{c}\text { Uncontrolled } \\
(5) \\
\end{array}$ & $\begin{array}{c}\text { Controlled } \\
(6) \\
\end{array}$ \\
\hline Social bank coefficient & -0.291 & -0.244 & -1.444 & -1.605 & -0.473 & -0.436 \\
\hline R-squared & 0.018 & 0.281 & 0.036 & 0.431 & 0.025 & 0.713 \\
\hline$\tilde{\beta}_{1}^{*}\left(R_{\max }=1\right.$ and $\left.\delta=1\right)$ & & -0.125 & & -1.835 & & -0.421 \\
\hline$\tilde{\beta}_{1}^{*}\left(R_{\max }=1.3\right.$ and $\left.\delta=1\right)$ & & -0.067 & & -1.957 & & -0.405 \\
\hline
\end{tabular}

Note: This table is based on the specifications displayed in Table 4. 